Maurer School of Law: Indiana University

Digital Repository @ Maurer Law

2003

\title{
Revolt Against or From Within the West?: TWAIL, the Developing World, and the Future Direction of International Law
}

David P. Fidler

Indiana University Maurer School of Law, dfidler@indiana.edu

Follow this and additional works at: https://www.repository.law.indiana.edu/facpub

Part of the International Law Commons

\section{Recommended Citation}

Fidler, David P., "Revolt Against or From Within the West?: TWAIL, the Developing World, and the Future Direction of International Law" (2003). Articles by Maurer Faculty. 2126.

https://www.repository.law.indiana.edu/facpub/2126

This Article is brought to you for free and open access by the Faculty Scholarship at Digital Repository @ Maurer Law. It has been accepted for inclusion in Articles by Maurer Faculty by an authorized administrator of Digital Repository @ Maurer Law. For more information, please contact rvaughan@indiana.edu. 


\title{
Revolt Against or From Within the West? \\ TWAIL, the Developing World, and the \\ Future Direction of International Law
}

\author{
David P. Fidler*
}

\section{Introduction: The Third World and the quest for a post- hegemonic global order}

The literature developing under the moniker "Third World Approaches to International Law" (TWAIL) critically analyzes international law in order to promote a more just and equitable approach to the countries and peoples of the developing world.' Mutua described TWAIL as a "broad dialectic of opposition to international law" that resists the illegitimate, predatory, oppressive, and unjust regime of international law.2 Gathii similarly argued that "Third World positions exist in opposition to, and as a limit on, the triumphal universalism of the liberal/conservative consensus in international law." ${ }_{3}$ Opposition to the prevailing system of international law from the perspective of Third World countries and peoples is not, of course, a new phenomenon in international legal analysis. ${ }^{4}$ TWAIL rejuvenates the

* Professor of Law and Ira C. Batman Faculty Fellow, Indiana University School of Law-Bloomington. An earlier version of this article was presented at "The 'Third World' and the International Order: Law, Politics, and Globalization," Osgoode Hall Law School, York University, Toronto, Canada, Oct. 13, 2001. The author thanks Amin M. Husain for his research assistance and the editors and reviewers of the Chinese Foumal of International Law for their comments and suggestions. This article was completed in February 2003.

1 The first academic conference dedicated to TWAIL occurred in March 1997 at Harvard Law School, at which the participants issued a vision statement that read in part: "We are a network of scholars engaged in international legal studies, and particularly interested in the challenges and opportunities facing 'third world' peoples in the new world order. We understand the historical scope and agenda of the dominant voice of international law and scholarship as having participated in, and legitimated global processes of marginalization and domination that impact on the lives and struggles of Third World peoples." Quoted in James Thuo Gathii, Alternative and Critical: The Contributions of Research and Scholarship on Developing Countries to International Legal Theory, 41 Harvard ILJ (2000), 273 n.46.

2 Makau Mutua, What is Twail?, 94 ASIL Proceedings (2000), 31.

3 James Thuo Gathii, Rejoinder: Twailing International Law, 98 Michigan LR (2000), 2067.

4 See, e.g., Gathii, above n.3, 2067; F. E. Snyder and S. Sathirathia (eds.), Third World Attitudes Toward International Law (1987), XI (presenting analyses of international legal scholars who have articulated, criticized, and evaluated the 
opposition to aspects of international law expressed by Third World states and intellectuals during the process of decolonization and attempts to sharpen such opposition in the era of globalization.

TWAIL is not, of course, the only perspective on the relationship between international law and the Third World; and this article's focus does not suggest that TWAIL is representative of Third World views on international law or the only scholarship in this area worth examining. Further, skepticism about "Third World perspectives on international law" has been present for decades, ${ }^{5}$ and such skepticism would also apply to TWAIL. The TWAIL project is, however, a high profile attempt to create an intellectual and political movement in international law that deserves attention because of the issues it raises and the approaches it promotes.

Scholars working under the TWAIL rubric do not necessarily share similar political, economic, or ideological beliefs. ${ }^{6}$ At the heart of TWAIL is, however, unity in "opposition to the unjust global order." 7 TWAIL opposition to the existing world order is both intellectual and political. Mutua described TWAIL's three basic objectives as follows:

The first is to understand, deconstruct, and unpack the uses of international law as a medium for the creation and perpetuation of a racialized hierarchy of international norms and institutions that subordinate non-Europeans to Europeans. Second, it seeks to construct and present an alternative normative legal edifice for international governance. Finally, TWAIL seeks through scholarship,

contribution of Third World nations to the development of international law); Antony Anghie, What is TWAIL: Comment, 94 ASIL Procecdings (2000), 39 ("The work of contemporary TWAIL scholars builds on and develops the work done by pioneering third world jurists").

5 See, e.g., Karin Mickelson, Rhetoric and Rage: Third World Voices in International Legal Discourse, 16 Wisconsin ILJ (1998), 353 ("There is no coherent or distinctive 'Third World approach' to international law; this appears to be the conventional view among international legal scholars. ... [t]he standard view expressed is that these disparate strands do not weave together in any sort of pattern. While for convenience they might be lumped together under the 'Third World' rubric, they constitute little more than a series of ad hoc responses to discrete issues. Even those who would admit the existence of a pattern tend to deny its distinctiveness").

6 Mutua, above n.2, 36 (arguing that TWAIL "does not ... have a specific creed or dogma"); TWAIL Vision Statement, http://www.als.cdu/faculty/jgathii/twail/ twailmain.htm (noting that members of the TWAIL network "may not agree on the content, direction and strategies of third world approaches to international law").

7 Mutua, above n.2, 36 . 
policy, and politics to eradicate the conditions of underdevelopment in the Third World. ${ }^{8}$

According to Mutua, TWAIL scholarship pursues these objectives by being anti-hierarchical, counter-hegemonic, suspicious of universal creeds and truths, and open to forming coalitions with other critical projects, such as critical race theory. ${ }^{9}$

TWAIL scholars have resurrected Third World opposition to international law because they perceive it again creates a hierarchy of cultures that privileges the West, underpins Western political and economic hegemony, and enshrines as global gospel the values, beliefs, and practices of Western, liberal civilization..$^{10}$ TWAIL seeks to (1) deconstruct the use of international law for creating and perpetuating Western hegemony; and (2) construct the bases for a post-hegemonic global order.

TWAIL's quest for a post-hegemonic global order is complex and defies simplistic description. In this article, I examine the conceptual nature of this quest because grappling with the quest's meaning is fundamentally important to TWAIL scholarship. In general terms, the TWAIL quest for a post-hegemonic global order is a quest for a more tolerant world in which the states and peoples of the Third World escape structural and substantive marginalization. Mutua argued that TWAIL advocates tolerance by assuming "the moral equivalency of cultures and peoples" and rejecting "othering,' the creation of dumb copies of the original." "ll Similarly, Gathii asserted that Third World approaches to international law are "characterized by the recognition of multiple identities, heterogeneity, and the rejection of universalist modes of reasoning." 12

TWAIL's attachment to tolerance is also apparent in its call "for the

8 Mutua, above n.2, 31.

9 Mutua, above n.2, 36-38. Other scholars have noted the potential connections between TWAIL and critical race theory. See, e.g., Elizabeth M. Iglesias, Out of the Shadow: Marking Intersections in and between Asian Pacific American Critical Legal Scholarship and Latina/o Critical Legal Theory, 40 Boston College LR (1998), 372 n.65; Gathii, above n.1, 274; Ediberto Roman, A Race Approach to International Law (RAIL): Is There a Need for Yet Another Critique of International Law?, 33 University of California Davis L.R (2000), 1534.

10 William J. Aceves, Critical Jurisprudence and International Legal Scholarship: A Study of Equitable Distribution, 39 Columbia JTL (2001), 302 (arguing that "the 'Third World' critique of international law questions the legitimacy of the international system. To these scholars, the colonial and imperial past of the international system is perpetuated in the contemporary rules and institutions of international law").

11 Mutua, above n.2, 36.

12 Gathii, above n.3, 2071. 
full democratization of the structures of both national and international governance so that all voices can be heard" and its opposition to "attempts to confer universality on norms and practices that are European in origin, thought, and experience."13 Discourse about the quest for a post-hegemonic global order suggests that scholars concerned about the Third World's relationship to international law believe that the current global order suffers from intolerance that harms a great deal of humanity.

TWAIL analysis of international law argues that the West's use of international law vis-à-vis the Third World embodies various forms of intolerance, from racism to denigration of non-Western cultural beliefs and practices to blind faith in liberalism's panacea.14 These concerns about intolerance mirror those of earlier Third World scholarship on international law. ${ }^{15}$ International law becomes a lens through which to examine intolerance in global politics and the search for a more tolerant global order that provides the Third World with not only space for self-determination but also bonds with the rest of humanity. The slogan for the quest for the post-hegemonic global order could be "unity in diversity." 16

The quest for a post-hegemonic order is not, however, new. As TWAIL acknowledges, the search for a post-hegemonic global order happened after World War II and during the period of decolonization from the 1950s through the 1970 s, 17 epitomized by the calls for a New International

13 Mutua, above n.2, 37.

14 See, e.g., Antony Anghie, Finding the Peripheries: Sovereignty and Colonialism in Nineteenth-Century International Law, 40 Harvard ILJ (1999), 1.

15 Upendra Baxi, Some Remarks on Eurocentrism and the Law of Nations, in: R. P. Anand (ed.), Asian States and the Develoment of Universal International Law (1972), 3 (arguing that Eurocentrism in international law "led to the acceptance, mostly uncritical, of European (and Western) intellectual and socio-cultural traditions as the invariable, if not superior, frameworks for enquiry. In its most acute form Eurocentrism has led to needless denigration of indigenous traditions of the colonized nations. But in its milder and more pervasive form it had led to a continuing indifference to these traditions even in the scholarly discourses"); Introduction, in: Third World Attitudes Toward International Law, above n.4, 3 (noting that the "struggle of the Third World entrants into an ungracious, unfriendly, and unaccommodating world community").

16 I base this notion of "unity in diversity" on Edmund Burke's pleas for "Unity of Spirit, though in a diversity of operations" in his writings on British policy toward the American colonies. See Edmund Burke, Speech on Conciliation with America, in: D. P. Fidler and J. M. Welsh (eds.), Empire and Community: Edmund Burke's Writings and Speeches on International Relations (1999), 133.

17 R. P. Anand, New States and International Law (1972), 46 (arguing that "what has been called the 'geography' of international law has radically changed. . . . [T] he majority in this expanded world community consists of small, weak, poor, underdeveloped, former colonies filled with resentment against their colonial 
Economic Order in the early 1970s. ${ }^{18}$ TWAIL scholarship has observed that this earlier quest failed.19 TWAIL angst about the post-Cold War Western, liberal hegemony in international law and relations provides evidence that the prior quest by the Third World for a post-hegemonic order left few, in any, significant traces in international law or the mindset of the Western hegemons.

The alleged failure of this earlier quest complicates the TWAIL pursuit for a more tolerant global order. The difficulty of the contemporary quest deepens when we realize that the hegemons are perhaps more united than during the period of decolonization. During the Cold War, the conflict between capitalism and communism divided hegemony along an East-West axis. With the Cold War over and liberalism triumphant, the hegemons of the international system share a philosophical unity not seen for many decades. In addition, the Third World is perhaps more fragmented, co-opted, and uncertain about what kind of opposition to mount. The Third World confronts today intolerance of a magnitude perhaps rivaled only by the "age of Empire."

My analysis proceeds in four parts. First, I look at the previous quest for a post-hegemonic international order that took place during the period of decolonization (Part II). Second, I consider the aftermath of the failure of this quest by exploring TWAIL concerns with the rise of a new hegemonic order centered on Western, liberal political power, practice, and philosophy (Part III). Third, I attempt to locate the current quest for a post-hegemonic global order in terms of a strategy against the alleged intolerance exhibited by the new liberal hegemony (Part IV). Fourth, I analyze the role intolerance plays in international law and the implications for the TWAIL quest for a posthegemonic order (Parts V-VI).

masters, and needing and demanding the protection of the international society. The new majority has new needs and new demands and they want law to serve their needs and heed to their demands. The alteration in the sociological structure of the international society, it is stressed, must be accompanied by an alteration in law").

18 GA Res. 3201 and 3202, Declaration and the Programme of Action on the Establishment of a New International Economic Order, May 1, 1974; GA Res. 3281, Charter of Economic Rights and Duties of States, Dec. 12, 1974 [hereinafter CERDS].

19 Anghie, above n.4, 39 (noting that very few proposals of Third World jurists for reform of the international system have been adopted); Anghie, above n.14, 75 (arguing that the effort to create a New International Economic Order failed). 


\section{The "revolt against the west": The attempted pluralization of Westphalian civilization}

\section{II.A. Pluralism and the development of Westphalian civilization}

The historical use of international law by Western states during the "age of Empire" to impose political, economic, and legal ideas and practices on non-Western states is familiar to this journal's readership and does not need elaboration. Through colonialism, capitulations, imperialism, and the standard of civilization, Western states built a structure for a global civilization based on the Westphalian model of international relations developed in postRenaissance Europe. By World War II, most of humanity was organized through a global "Westphalian civilization."20 Westphalian civilization contains structural and substantive features.

Structurally, Westphalian civilization is composed of sovereign states interacting in a condition of anarchy. ${ }^{21}$ For order to be maintained in such a system, states require substantive rules to regulate their interaction, rules originally called the law of nations and later international law.22 Because of the anarchical nature of their relations, states themselves decide the substantive content of the rules regulating their intercourse. Civilizational affinity informs the substantive content of the rules of international law. International legal literature recognizes that the structure and substantive rules of state interaction in international relations were entirely of Western origin. ${ }^{23}$

20 On the concept of "Westphalian civilization," sce David P. Fidler, The Return of the Standard of Civilization, 2 Chicago JIL (2001), 140-146.

21 Christopher Harding and C. L. Lim, The Significance of Westphalia: An Archaeology of the International Legal Order, in: C. Harding and C. L. Lim (eds.), Renegotiating Westphalia: Essays and Commentary on the European and Conceptual Foundations of Modern International Law (1999), 5-6 ("As an event in the history of international relations the Treaty of Westphalia symbolically indicated a sea-change in international organisation-the transition to a system of sovereign states, as sovereigns subject to no higher or competing authority and conveniently determining the number and character of their legal relations with each other").

22 Antonio Cassesse, International Law in a Divided World (1986), 9 ("The first salient feature of international law is that it aims at regulating the behaviour of States, not that of individuals").

23 Josef L. Kunz, Pluralism of Legal and Value Systems and International Law, 49 AJIL (1955), 371 (1955) ("Our international law is a crcation of Christian Europe"); Anand, above n.17, 45 (arguing that "even a cursory look at the history of international law leaves no doubt about the Eurocentric nature of this law developed by and for the benefit of the rich, industrial, and powerful states of Western Europe and the United States"); Wang Tieya, The Third World and 
Before the global expansion of European power, Westphalian civilization was not, however, monolithic in terms of how sovereign states structured politics, economics, and society. Westphalian civilization evolved in Europe for at least three centuries before it burst onto the rest of the world through colonialism and imperialism in the nineteenth century. ${ }^{24}$ "Westphalian" comes from the Peace of Westphalia (1648), which scholars regard as the formal beginning of the modern inter-state system.25 The Peace of Westphalia ended the Thirty Years' War (1618-1648), a bloody Europeanwide conflict between Protestant and Catholic powers that, at the time, represented "the most devastating European conflict after the barbarian invasion." 26

The Thirty Years' War was, in large part, a war of religious intolerance between Catholicism and Protestantism. The Peace of Westphalia gave official birth to a European inter-state system that removed internal issues, such as whether a country was Catholic or Protestant, from the realm of international politics.27 Non-intervention in the domestic affairs of other states was, thus, a structural and substantive component of the Westphalian system. In short, Westphalian civilization began in the seventeenth century with an attempt to create a stable structure for inter-state relations that excluded the nature of domestic politics, economics, and society from being a concern of diplomacy and the law of nations. Westphalian civilization began

International Law, in: R. St. J. Macdonald and D. M. Johnston (eds.), The Structure and Process of International Law (1983), 959 ("Intcrnational law originated in the west as a product of European civilization"); Robert H. Jackson, The Evolution of International Society, in: J. Baylis and S. Smith (eds.), The Globalization of World Politics (2nd ed., 2001), 44 (obscrving that "there is little doubt that modern international society is rooted in the political culture and political thought of the European peoples"). Some scholars have argued for more diverse origins of international law, including the participation of more than one civilization. See, e.g., Roberto Ago, Pluralism and the Origins of the International Community, 3 Italian YIL (1977), 3.

24 For a historical analysis of the pre-Westphalian development of the international system and international law, see Wilhem G. Grewe, The Epochs of International Law (M. Byers. trans., 2000), 35-275; Arthur Nussbaum, A Concise History of the Law of Nations (Rev. ed., 1954), 1-114.

25 Jan Aart Scholte, The Globalization of World Politics, in: The Globalization of World Politics, above n.23, 20 ("The name is derived from the Peace of Westphalia (1648), which contains an early official statement of the core principles that came to dominate world affairs during the subsequent threc hundred years").

26 Nussbaum, above n.24, 115.

27 Jackson, above n.23, 43 (noting that a central principle of Westphalian international society was cujus regio, ejus religio-the ruler determines his realm's religion). 
as a pluralistic project, ${ }^{28}$ ostensibly tolerant of domestic differences among European states. ${ }^{29}$ Westphalian civilization was intolerant toward attempts by any European nation to disrupt the balance of power, ${ }^{30}$ as evidenced by the wars waged to prevent one state, such as Spain or France, from imposing its will on the rest of Europe. Thus, Westphalian civilization began its historical march as structurally intolerant of imbalanced power among European states but substantively tolerant of domestic differences within European states.

The substantive tolerance of Westphalian civilization should be considered in light of the common geographical, historical, religious, legal, economic, and cultural heritage the European countries and peoples shared. The tolerance of Westphalian civilization about the domestic affairs of states rested on a likemindedness about politics, law, economics, and culture.31 Westphalian civilization's pluralism in Europe was not a pluralism of radically diverse beliefs and practices. As evidenced by Europe's uneasy relationship with the Ottoman Empire, ${ }^{32}$ pluralism in Westphalian civilization was still Eurocentric.

The French Revolution and the wars it sparked tested both the

28 Jackson, above n.23, 44 (noting efforts of Westphalian international society to maintain "the pluralist European society of states").

29 Grewe, above n.24, 287-294 (analyzing the development of the inter-state system after 1648 "in the age of tolerance").

30 Jackson, above n.23, 44 (noting Westphalian international society's "antihegemonial notion of a countervailing alliance of major powers aimed at preserving the freedom of all states"). See also F. H. Hinslcy, Power and the Pursuit of Peace: Theory and Practice in the History of Relations Between States (1963), 167-175 (analyzing the balance of power in early modern Europe after the Peace of Westphalia).

31 Edmund Burke captured this shared heritage in 1796, when he wrote:

[Europe] is virtually one great state having the same basis of general law; with some diversity of provincial customs and local establishments. The nations of Europe have had the very same christian religion... . The wholc of the polity and oeconomy of every country in Europe has been derived from the same sources. . . From all those sources arose a system of manners and of education which was nearly similar in all this quarter of the globe; and which softened, blended, and harmonized the colours of the whole. . . From this resemblance in the modes of intercourse, and in the whole form and fashion of life, no citizen of Europe could be altogether an exile in any part of it. . . . When a man traveled of resided for health, pleasure, business or necessity, from his own country, he never felt himself quite abroad.

Edmund Burke, First Letter on a Regicide Peace, in: Empirc and Community, above n. 16, 315-316.

32 See, e.g., Thomas Naff, The Ottoman Empire and the European States System, in: H. Bull and A. Watson (eds.), The Expansion of International Society (1984), 143. 
structural intolerance and substantive tolerance of Westphalian civilization. The other European powers struggled with whether (1) traditional balance of power politics would suffice to deal with the French irruption; or (2) intervention into French affairs was needed to restore the ancien regime and European stability and to destroy Jacobinism as a transnational ideology. This debate continued after Napoleon's defeat in the different policy positions of Great Britain-keeper of the European balance of power-and the continental powers of the Holy Alliance (e.g., Russia), which were determined not to allow something like the French Revolution to plague European order again. ${ }^{33}$ Largely through British influence, Westphalian civilization returned to its traditional pattern of structural intolerance toward imbalanced power in Europe and substantive tolerance toward diversity in domestic affairs.

In the "age of Empire," Westphalian civilization turned intolerant of domestic differences when European states brought non-Western nations and peoples into the Westphalian system. The imposition of the mechanics of Westphalian civilization on the non-Western world universalized international law in the nineteenth century, but it did not completely homogenize the world in the West's image. Homogenization on Western models made progress in the nineteenth and early twentieth centuries through the application of the standard of civilization, ${ }^{34}$ but Westphalian civilization exploded at its core in World War I-the structural intolerance of the system leading Europe into the bloodiest conflict ever seen.

World War I interrupted the homogenization of the non-Western world, and this process did not get back on course until later in the twentieth century. In terms of international law, Grewe has written that "[t]he nineteenth century idea of a society of civilized nations ... did not survive the First World War as a basis and framework for international law" and that " $[t]$ he intellectual substance of the international legal community changed during the two decades of the inter-war period, above all as a result of the fading away of the civilisational ideology and the indiscriminate extension of the international legal order to all States, regardless of their race, culture or geographical location." 35

33 Hinsley, above n.30, 199-212 (analyzing the conflict between Britain and the states composing the Holy Alliance about the nature of the balance of power in Europe).

34 See generally Gerrit W. Gong, The Standard of 'Civilization' in International Society (1984).

35 Grewe, above n.24, 581-582, 581 . 


\section{II.B. Pluralism, Westphalian civilization, and the Cold War international system}

The end of World War II found Westphalian civilization poised on the brink of great pluralism. The Soviet Union had emerged as a great power utilizing an ideology that challenged the liberal, capitalist assumptions that drove the West's prior universal expansion. The former imperial and colonial territories began to form new sovereign states in a decolonization process that would continue for three decades, creating new actors with diverse cultural and civilizational histories and different political and economic interests from the West. As Linklater observed, "the sovereign state has been accepted by non-European peoples and there is a basic consensus about the need to uphold basic rules of co-existence though not to promote any particular set of moral standards." ${ }_{36}$ The traditional structural intolerance and substantive tolerance of Westphalian civilization universalized under the forces of international politics after World War II.

The "revolt against the West" 37 by developing countries, at least as played out in international law, attempted to expand and deepen the pluralization of international relations. The pluralization efforts had procedural and substantive features. Procedurally, developing countries sought to change the hegemonic process through which international law was historically made and implemented. The process of decolonization assisted procedural pluralization because it increased the number of new, developing states in the international system.

The creation of many new states changed the dynamics of international law in two ways. First, these states began to exercise their rights as states under international law, creating a significant body of state practice affecting treaty and customary international law that could not be ignored. Second, developing states became members of international organizations, such as the United Nations, and began to influence the process of international law through participation in debates, decisions, and cooperative activities undertaken in these institutions. Developing countries used their growing quantitative presence in the international system to try to ensure that the manner in which international law was made and implemented no longer reflected only the interests and prejudices of the great powers of the West.

Substantively, developing countries attempted to change the content of areas of international law so that the rules would reflect their interests and not just those of their former colonial overlords. ${ }^{38}$ As indicated above, developing

36 Andrew Linklater, Rationalism, in: S. Burchill and A. Linkater (eds.), Theories of International Relations (1996), 106.

37 The phrase "revolt against the West" comes from Hedlcy Bull, The Revolt Against the West, in: The Expansion of International Society, above n.32, 217.

38 Harding and Lim, above n.21, 2 (arguing that "the newly independent states in 
countries engaged themselves in virtually every area of international law through their diplomatic activities with other countries and through international organizations. The strategic aim of substantive pluralization can be, however, discerned in areas of international law on which the Third World focused significant attention, namely the principle of selfdetermination, the prohibition on intervention in the domestic affairs of other states, international law on foreign direct investment, international trade law, the law of the sea, and the establishment of a New International Economic Order.

\section{II.B.i. Principle of self-determination}

Although self-determination existed as an issue in international relations prior to decolonization, ${ }^{39}$ developing countries elevated this principle in the post-World War II period. 40 The emphasis the Third World placed on this principle reflects, foremost, the desire to rid the international system of the lingering vestiges of colonialism. The principle of self-determination proved a powerful legal and moral weapon to push back Western influence and create political, economic, legal, and cultural space for the states and peoples of the developing world to determine their own destinies, not destinies determined by colonial powers and civilizational prejudices.

\section{II.B.ii. Non-intervention in the domestic affairs of other states}

For developing countries, the fruits of self-determination were the newly independent states emerging from the former Western empires. The political space gained through self-determination remained vulnerable because of the inequalities in power and influence still alive in post-colonial

Asia and Africa argued for the introduction of new legal concepts into the corpus of classical international legal doctrine").

39 UN Charter, art. 1(2) (stating that a purpose of the United Nations was "[t]o develop friendly relations among nations based on respect for the principle of equal rights and self-determination of peoples"). See also Antonio Cassesse, SelfDetermination of Peoples: A Legal Appraisal (1995), 11-33 (analyzing the historical background of the self-determination principle).

40 See, e.g., GA Res. 1514(XV), Declaration on Granting Independence to Colonial Countries and Peoples, Dec. 14, 1960; GA Res. 2625 (XXV), Declaration on Principles of International Law Concerning Friendly Relations and Co-operation Among States in Accordance with the Charter of the United Nations, Oct. 24, 1970 [hereinafter Declaration on Friendly Relations] (highlighting the "principle of equal rights and self-determination of peoples"); CERDS, above n.18, Chapter 1 (asserting that economic and political relations among states shall be governed by, among other principles, "[e]qual rights and self-determination of peoples"). 
international relations. As part of the pluralization strategy, developing countries worked to elevate and reinforce the principle of non-intervention in the domestic affairs of other states. As mentioned above in the discussion of the development of international law in Westphalian civilization, ${ }^{41}$ developing countries did not create the non-intervention principle, which had been part of international law for centuries.

Through the efforts of developing countries, however, the principle of non-intervention was the subject of significant international emphasis. As the UN General Assembly Declaration on Friendly Relations (1970) stated, "[n]o state or group of States has the right to intervene, directly or indirectly, for any reason whatsoever, in the internal or external affairs of any other State. . . . Every state has an inalienable right to choose its political, economic, social and cultural systems, without interference in any form by another State." 42

The process of decolonization created, however, an increased geographical scope for the non-intervention principle, transforming this principle from a European into a universal rule of international law. By pushing the non-intervention principle, developing countries continued their attempts to roll back colonial and neo-colonial interference with their affairs. The non-intervention principle supported the effort by developing countries to create room for their own policies to take shape within their territories.

Third World emphasis on the principles of self-determination and non-intervention represented the utilization of existing international law to craft a more pluralistic, tolerant international system. ${ }^{43}$ Although neither of these principles were original to developing-country thinking, their application by the developing countries represented a substantive transformation in international law and relations. Principles of emancipation and political tolerance of domestic differences previously reserved for inter-European relations became universal.

41 See text to $n .27$ above.

42 Declaration on Friendly Relations, above n. 40.

43 The use of the principles of self-determination and non-intervention by the Third World illustrates that it was not entirely hostile toward the system of international law. As Wang argued, "[a]though Third World countries are adamantly opposed to the imperialistic, colonialistic, oppressive and exploitative principles and rules of traditional international law, they do not reject international law itself. . . . The attitude of the Third World towards international law is very clear: it neither accepts nor rejects international law in its entirety." Wang, above n.23, 961, 962. 


\section{II.B.iii. International law on foreign direct investment}

The developing world's assault on the international law on foreign direct investment is often cited as an example of the "revolt against the West" having impact on international law.44 Just as effective self-determination required renewed emphasis on the principle of non-intervention, the developing world's substantive pluralization of international law confronted rules of international law that provided powerful, Western states with opportunities to intervene in domestic matters of developing states. Unlike developing-country exploitation of existing international legal principles, the attack on the customary international law on the protection of foreign direct investment embodied new substantive ideas that challenged the status quo.

The international legal controversies about the international law on foreign direct investment precede the "revolt against the West," 45 but the effort to transform this area of international law achieved greater momentum during the decolonization period because of the individual and coordinated efforts of developing countries. ${ }^{46}$ At the heart of the attack on the customary rules on foreign direct investment, such as the principles of diplomatic intervention and prompt, adequate, and effective compensation for expropriations, was the strategy of making economic sovereignty effective. Self-determination produced formal sovereignty, and the principle of non-intervention offered general protection for the exercise of such sovereignty. Developing countries perceived, however, that traditional international law on foreign direct investment undermined the effective exercise of their sovereignty in the economic realm by giving capital-exporting states and their corporations the ability to constrain policy options.

In effect, the attack on the customary rules of international law on foreign direct investment represented an effort to reduce the significance of international law in this area of international relations. The emphasis on "permanent sovereignty" over economic resources conceptually rejected a significant role for international law in matters of foreign investment. ${ }^{47}$ Matters

44 See, e.g., Anand, above n.17, 47 (arguing that developing states successfully challenged international law relating to the responsibility of states); Felix C. Okoye, International Law and the New African States (1972), 178-184 (analyzing the contribution of new African states to the Third World's challenge against the traditional international law on foreign investment).

45 See M. Sornarajah, The International Law on Forcign Investment (1994), 8-12 (reviewing the history of international law on foreign investment prior to the postcolonial period).

46 See, e.g., GA Res. 1803 (XVII), Permanent Sovereignty Over Natural Resources, Dec. 14, 1962; CERDS, above n.18, art. 2.

47 One can see the desire to reduce the role for international law in the treatment of 
relating to the regulation of foreign investment should, as a result, be determined according to domestic law and policy with minimal scope for challenging such sovereign acts through international law.

This perspective explains the Third World move to replace the Hull Doctrine of prompt, adequate, and effective compensation for expropriation with a standard that provided the host government more latitude in assessing the appropriate level of compensation due an investor. Developing countries were successful in this effort, as reflected by the admission of the United States Supreme Court in 1964 that international law on expropriation of foreign direct investment was the source of great diplomatic disagreement and controversy. ${ }^{48}$

\section{II.B.iv. Special and differential and treatment under international trade law}

The three previous examples focused on efforts made to demarcate political, economic, and legal space in which developing countries could determine their own futures. The substantive pluralization strategy did not, however, stop there. Although developing countries believed it important to gain, protect, and effectuate their sovereignty, they also understood that embracing "formal equality" through international law would be inadequate for the development of their societies. The inequalities in wealth, economic capabilities, and standard of living between developed and developing countries were too stark for the Third World to rely merely on abstract sovereign equality. Developing countries needed help from developed countries, and they attempted to use international law to create ways in which such help could materialize.

One area in which special and differential treatment for developing countries emerged was international trade law under the General Agreement on Tariffs and Trade (GATT). ${ }^{49}$ Adopted in 1947, GATT promulgated rules

foreign direct investment by comparing provisions from the Resolution on Permanent Sovereignty over Natural Resources (1962) and the CERDS (1974). The Resolution on Permanent Sovereignty over Natural Resources states that owners shall be paid appropriate compensation for expropriated property in accordance with national law and "in accordance with international law." Resolution on Permanent Sovereignty over Natural Resources, above n.46, para. 4. The CERDS provides, however, that appropriate compensation to an expropriated owner of property should be paid "taking into account its relevant laws and regulations," but the Charter does not mention international law. CERDS, above n.18, art. 2.2(c).

48 Banco Nacional de Cuba v. Sabbatino, 376 U.S. 398, 429 (1964) ("There are few issues in international law today on which opinion seems to be so divided as the limitations on a state's power to expropriate the property of aliens").

49 General Agreement on Tariffs and Trade, Oct. 30, 1947 [hercinafter GATT]. 
regulating the international trade in goods, such as the most-favored-nation ${ }^{50}$ and national treatment ${ }^{51}$ principles, designed to create a level playing field for GATT parties. GATT originally contained little recognition that, for most developing countries, the concept of a "level playing field" was unrealistic and of limited help in terms of economic development. Formally, GATT rules were non-discriminatory because they applied equally to all contracting parties, which as sovereign states had equal rights and duties under international law. Practically, developing countries were not "equal" with most of the great trading powers behind GATT's creation and implementation.

As more developing countries joined GATT, they began to push for special and differential treatment for developing countries. ${ }^{52}$ This effort confronted a legal problem in the most-favored-nation principle, which prohibits (as a general matter) GATT parties from discriminating in favor of one contracting party in terms of the treatment of like products imported from or exported to two or more contracting parties. 53 To allow special and differential treatment under GATT, the contracting parties would have to relax the most-favored-nation principle. GATT exempted bilateral and regional free trade agreements from the most-favored-nation principle under specified conditions ${ }^{54}$ but otherwise did not include a special regime for developing countries.

In the 1960s, the developing contracting parties of GATT succeeded in getting developed countries to agree to special and differential treatment for trade in goods concerning developing countries. Part IV on "Trade and Development" was added to GATT;55 and, pursuant to this new body of principles, developed countries began to adopt general systems of preferences in the late 1960s and early 1970s that accorded developing countries preferential tariff treatment. ${ }^{56}$ GATT parties enacted a ten-year waiver of the most-favored-nation principle in 1971 to exempt GSP efforts from the application of this principle, a waiver the GATT contracting parties made

so GATT, above n.49, art. I.

51 GATT, above n.49, art. III.

52 The United Nations Conference on Trade and Development (UNCTAD) first introduced he concept of a general system of trade preferences for developing countries in 1964. Raj Bhala, International Trade Law: Theory and Practice (2nd ed., 2001), 1431.

53 GATT, above n.49, art. I.

54 GATT above n.49, art. XXIV.

55 Protocol Amending the General Agreement on Tariffs and Trade to Introduce a Part IV on Trade and Development, GATT Basic Instruments/ Selected Documents (July 1965), 13S/2-10. 
permanent in 1979.57

The developing world's success in embedding special and differential treatment into international trade law represents another aspect of the substantive pluralization strategy because special and differential treatment, conceptually, acknowledged the particular dilemmas many developing countries faced. The changes made in GATT law and practice constitute a substantive shift in international law towards basing the application of important international legal rules on a state's level of economic development rather than on the traditional approach of all sovereign states bearing equal and identical obligations under international law.

\section{II.B.v. Law of the sea}

Developing countries also had significant impact on the international law of the sea during the UN-sponsored law of the sea negotiations in the 1970s that produced the UN Convention on the Law (UNCLOS, 1982)..$^{58}$ This effort to influence the substantive content of international law echoes the developing world attempt to re-conceptualize international trade law in the 1960s to include special and differential treatment; but, in the law of the sea negotiations, developing countries proposed bolder concepts and rules than special and differential treatment. Although developing country input featured in the creation of many new elements of the law of the sea to emerge from the negotiations in the 1970s (e.g., the creation of the regime for archipelagic states ${ }^{59}$ ), two of the best known substantive achievements of the developing world in this international legal context are the "exclusive economic zone" $(\mathrm{EEZ})^{60}$ and the "common heritage of mankind" (CHM).61

Both the EEZ and CHM concepts centered on a key problem the law of the sea negotiations faced-how to allot jurisdiction over living and nonliving marine resources beyond the limits of national jurisdiction. Other facets of the law of the sea, such as the breadth of the territorial sea and the regime on the exploitation of the resources on and beneath the continental shelf, factored into resolving this problem, but the developing world played a key role in formulating two new substantive legal regimes to deal with two unresolved resource allocation issues: jurisdiction over (1) living and non-living marine resources adjacent to a coastal state's territorial sea but not covered by

57 Bhala, above n.52, 1430 .

58 United Nations Convention on the Law of the Sea, Dec. 10, 1982 [hercinafter UNCLOS].

59 UNCLOS, above n. 58 , arts. 46-54.

60 UNCLOS, above n.58, arts. 55-75.

61 UNCLOS, above n.58, art. 136 (stating that all non-living resources in the area beyond national jurisdiction "are the common heritage of mankind"). 
the continental shelf rules (EEZ); and (2) non-living resources on or beneath the ocean floor in the area beyond national jurisdiction (CHM).

Prior to the law of the sea negotiations, international law, generally speaking, considered living and non-living marine resources beyond the territorial sea and not subject to the continental shelf regime to be subject to the freedom of the high seas, meaning such resources were open for exploitation by any state.62 From the developing country perspective, this situation meant that international law would allow developed countries to appropriate the lion's share because only developed countries would have the capability of harvesting such resources on a commercial scale.63 Developing countries successfully proposed the EEZ concept, under which the coastal state had, if it desired, the right to declare its exclusive jurisdiction over economic resources out to 200 nautical miles from the coast. ${ }^{64}$ Such a proposal would benefit coastal developing countries concerned about the vulnerability existing international law created for developing-country access to marine resources. At the same time, the EEZ concept was not reserved for developing countries, making it a traditional "equal opportunity" concept from which developed states could also benefit. 65

The EEZ concept did not, however, regulate non-living marine resources on or beneath the ocean floor beyond 200 nautical miles from the coast and not covered by the continental shelf regime. The traditional "freedom of the high seas" principle essentially meant that any state could exploit these resources, which included mineral-rich deposits. Developed countries could, thus, legally exploit these resources for their own benefit, creating the potential for an exploitation regime that would offer no benefit to the world's poor countries. ${ }^{66}$ Instead of this traditional regime, the developing

62 R. R. Churchill and A. V. Lowe, The Law of the Sea (1983), 156 (noting that "the abyssal plains of the ocean beds would, in the absence of any special rules, be regarded as subject to the freedoms of the high seas").

63 Churchill and Lowe, above n.62, 125 (describing developing-country interest in the EEZ concept flowing from the desire gain control over resources "largely exploited by the distant-water fleets of devcloped States") and 157 (noting that, under the freedoms of the high seas rules, "the developed States of the West, which alone could muster the necessary investment and technology, would be the main beneficiaries of sea-bed mining").

64 Shigeru Oda, Exclusive Economic Zone, in: EPIL (1995), 307 (reporting on Kenya's introduction of the EEZ concept to the UNCLOS negotiations in 1972 and the support it gathered from developing states). Kenya had previously raised the concept in the Asian-African Legal Consultative Committee in 1971. Churchill and Lowe, above n.62, 125.

65 UNCLOS, above n.58, art. 56.1 (stating that coastal states have sovereign rights over the economic resources on the EEZ).

66 Deep sea-bed mining dominated by developed states had two potential 
world championed the CHM concept, under which the resources in question would be exploited under an international authority predominantly for the benefit of developing countries. ${ }^{67}$ The CHM concept proposed to add to international law not only a novel institution but also a scheme of distributive economic justice. This approach deepened the substantive pluralization of international law undertaken by the developing world because it went beyond special and differential treatment to champion ideas about the management of global economic resources alien to traditional concepts of international law.

\section{II.B.vi. New international economic order}

The EEZ and CHM concepts can be seen as precursors of another, even bolder Third World effort to reshape international law-the New International Economic Order (NIEO). ${ }^{68}$ As Third World emphasis on nonintervention and attempts to change the substantive rules of international law in the areas of foreign direct investment, trade, and the law of the sea illustrate, developing countries' efforts sought to transform the way in which international law regulated economic intercourse between states. The various efforts on this issue converged in the NIEO, which laid out an alternative vision for economic relations between states that stressed strong principles of sovereignty and non-intervention, national control over foreign investment, and the need to have economic policy recognize the development challenges faced by developing countries. ${ }^{69}$ In fact, one of the key NIEO documents, the Charter of Economic Rights and Duties of States (Charter) represents in many respects a capstone for each of the Third World international legal efforts

disadvantages for developing states: (1) only developed states had the technological capability to exploit the resources in the area beyond national jurisdiction; and (2) developed-country commercial exploitation of minerals from the deep sea-bed might adversely affect the prices of land-based minerals traded by developing countries. See Churchill and Lowe, above n.62, 155-157.

67 UNCLOS, above n.58, art. 137.2 ("All rights in the resources of the Area are vested in mankind as a whole, on whose behalf the Authority shall act").

68 A. O. Adede, The Minimum Standards in a World of Disparities, in: The Structure and Process of International Law, above n.23, 1021 ("The 'New International Economic Order' is . . . aimed at achieving morc access to and distribution of the world's riches though legal instruments in which the rights and interests of all the actors in the world arena are fully protected"). On the NIEO and international law generally, see K. Hossain (ed.), Lcgal Aspects of the New International Economic Order (1980); R. P. Anand, Confrontation or Cooperation? International Law and the Developing Countries (1987), 103-128; Jerzy Makarczyk, Principles of a New International Economic Order: A Study in International Law Making (1988).

69 See CERDS, above n.18. 
outlined above. Table 1 below summarizes how the Charter captures these previous initiatives in its substance.

Table 1.

\begin{tabular}{|c|c|}
\hline $\begin{array}{c}\text { Substantive Legal } \\
\text { Issue }\end{array}$ & $\begin{array}{l}\text { Examples of Provisions from the Charter of } \\
\text { Economic Rights and Duties of States }\end{array}$ \\
\hline Self-Determination & $\begin{array}{l}\text { "Economic as well as political and other relations } \\
\text { among States shall be governed, inter alia, ... Equal } \\
\text { rights and self-determination of peoples."-Chapter } 1 .\end{array}$ \\
\hline Non-Intervention & $\begin{array}{l}\text { "Every State has the sovereign and inalienable right to } \\
\text { choose its economic system as well as its political, } \\
\text { social and cultural systems in accordance with the will } \\
\text { of its people, without outside interference, coercion or } \\
\text { threat in any form whatsoever."-Chapter II, Article } \\
1\end{array}$ \\
\hline $\begin{array}{l}\text { Foreign Direct } \\
\text { Investment }\end{array}$ & $\begin{array}{l}\text { "Each State has the right: (a) To regulate and exercise } \\
\text { authority over foreign investment within its national } \\
\text { jurisdiction in accordance with its own laws and } \\
\text { regulations and in conformity with its national } \\
\text { objectives and priorities. . . . (b) To regulate and } \\
\text { supervise the activities of transnational corporations } \\
\text { within its national jurisdiction and take measures to } \\
\text { ensure that such activities comply with its laws, rules } \\
\text { and regulations and conform with its economic and } \\
\text { social policies. . . (c) To national, expropriate or } \\
\text { transfer ownership of foreign property, in which case } \\
\text { appropriate compensation should be paid ... taking } \\
\text { into account its relevant laws and regulations and all } \\
\text { circumstances the State considers pertinent."- } \\
\text { Chapter II, Article } 2\end{array}$ \\
\hline $\begin{array}{l}\text { Special and } \\
\text { Differential } \\
\text { Treatment in } \\
\text { International Trade }\end{array}$ & $\begin{array}{l}\text { "Developed countries should extend, improve and } \\
\text { enlarge the system of generalized non-reciprocal and } \\
\text { non-discriminatory tariff preferences to the developing } \\
\text { countries ..." Chapter II, Article } 18\end{array}$ \\
\hline Law of the Sea & $\begin{array}{l}\text { "The sea-bed and ocean floor and the subsoil thereof, } \\
\text { beyond the limits of national jurisdiction, as well as the } \\
\text { resources of the area, are the common heritage of } \\
\text { mankind."-Chapter III, Article } 29 \text {. }\end{array}$ \\
\hline
\end{tabular}

The examples described above of Third World efforts to pluralize the process and substance of international law in the post-World War II period 
are by no means comprehensive, and other illustrations could be analyzed..$^{70}$ These examples are, however, sufficient to demonstrate that the Third World's "revolt against the West" in international law involved expanding and deepening pluralization in international relations and to create, nurture, or foster rules that would produce more substantive tolerance among states than had been the case in the imperial age. This attempted Third World pluralization of Westphalian civilization gave non-Western states the opportunity to develop identities and transnational solidarity independent of the views and interests of their previous civilizational overlords. Through such identities and solidarity, developing states mounted substantive and determined opposition to the inherited Eurocentric rules and assumptions of Westphalian civilization.

The Soviet challenge to Western liberalism and capitalism afforded the developing world structural room for maneuver in its pluralization strategy because the Soviet Union was a superpower with global reach opposed to liberal ideology. The Soviet Union provided a counter-weight against Western power that gave developing countries structural space in which to pursue pluralization. In other words, structural intolerance to an imbalance of power during the Cold War worked in favor of the Third World's pluralization quest. The end result would be, it was hoped, a post-hegemonic order that recognized the distinctiveness of the Third World's interests and cultures. ${ }^{71}$

\section{The post-Cold War triumph of the West: The attempted homogenization of Westphalian civilization}

\section{III.A. Pluralization lost}

TWAIL literature argues that traces of the Third World's "revolt against the West" cannot be easily located today in international law. TWAIL scholars question the impact developing countries had during the Cold War on international law. Anghie's assertion that "the drive by developing countries to create a 'New International Economic Order' ended, on the whole, in failure" 72 represents an observation on more than one element of the Third World effort because, as discussed above, the NIEO embodied the substantive and procedural thrust of the "revolt against the West." Although not all scholars of the Third World's relationship with international law would agree with such TWAIL pessimism, for purposes of this article it is necessary

70 For a broader analysis of quantitative and qualitative impact on international law by developing countries, see Wang, above n.23, 955-976.

71 Anand, above n.17, 48-52 (discussing the importance and influence of cultural differences to and on international law).

72

Anghic, above n.14, 75 . 
to explore briefly where the procedural and substantive pluralization efforts of developing countries in the Cold War period stand today.

As argued above, efforts at procedural pluralization by developing countries sought to ensure that the way in which international law was created and operationalized would reflect more than the interests of the Western great powers. In the post-Cold War period, a frequently heard complaint is that effective participation by developing countries in international politics is lacking. The complaint has been acute in the realm of international economics, a key area targeted in the "revolt against the West." Analysis of the World Trade Organization (WTO) and international financial institutions, such as the World Bank and the International Monetary Fund (IMF), frequently mentions the problem of the Third World's lack of effective participation.

In connection with the WTO, Bhala argued that Third World countries face a "[n]ear impossibility of effective participation":

Even if Third World WTO members comprehended and fully implemented the legal agreements from the previous trade round, they could hardly be expected to keep up with the pace of activity at the WTO. Indeed, they have virtually no say over that pace. The key WTO members, in terms of setting agendas and priorities, organizing meetings, formulating positions, and so forth, are the usual suspects. Many developing countries cannot participate fully in WTO affairs as structured by members like the United States.73

The lack of effective participation by developing countries in the implementation of WTO agreements undermines the continued, and even expanded, presence of special and differential treatment for developing countries found in the Uruguay Round agreements. In other words, the success the Third World had embedding special and differential treatment for developing countries as a substantive principle in GATT has survived and even multiplied in the WTO agreements. ${ }^{74}$ Despite the formal success of the special and differential approach, questions remain about whether the international trading system, as modified to acknowledge the needs of developing countries, has produced the benefits promised for the Third

73 Raj Bhala, Poverty, Islam, and Doha: Unmet Challenges Facing American Trade Law, 36 International Lawyer (2002), 171.

74 For an analysis of special and differential treatment in the agreements of the WTO, see Raj Bhala, Trade, Development, and Social Justice (2003) (forthcoming). 


\section{World. ${ }^{75}$}

The seriousness of the Third World's troubled relationship with international trade law of the WTO appears in the decision to focus the next round of trade liberalization talks on Third World development-the socalled Doha Development Agenda. ${ }^{76}$ Although it is too early to judge whether the next round of negotiations will advance the economic development of developing countries, pessimism is in the air. Reflecting on this atmosphere, Bhala noted that "a poor country might well view the Doha result not so much as a success, but as an extension of the Ancient Greek Melian Dialogue to international trade relations: that the strong do what they do, and the weak suffer what they must." $" 7$

Experts have voiced similar sentiments on the lack of procedural pluralization in connection with the World Bank and IMF. With regard to these international financial institutions, Woods argued that "decision-making processes have remained the same and rely on a hierarchy which reflects fiftyyear-old inequalities" and still require fundamental changes that would produce "greater legitimacy, and a greater degree of representation and participation .. . which is unlikely given the persistence of the old hierarchy."78 As I observed elsewhere, the World Bank's and IMF's power "is, by and large, controlled by the same group of 'civilized' powers that were responsible for the creation of the multilateral system of capitulations-the European countries and the United States."79

The quantitative advantage decolonization gave developing countries in international law and organizations during the Cold War does not appear to have created the conditions under which the procedural pluralization of international decision-making desired by the Third World has occurred. Woods concluded her analysis in TWAIL-like fashion by arguing that "in the organizations and institutions which are needed to regulate and facilitate international issues, there is little indication that powerful member states have

75 Bhala, above n.73, 168 (arguing that "on balance, the perception is that the legal regime of the General Agreement on Tariffs and Trade (GATT) and WTO do not deliver the net benefits-in the form of faster growth and income-poverty reduction - that the First World and its economic theorists claim").

On the Doha Development Round, see World Trade Organization, Doha Development Agenda, http://www.wto.org/cnglish/tratop_c/dda_c/dda_e.htm.

77 Bhala, above n.73, 173-174.

78 Ngaire Woods, Order, Globalization, and Inequality in World Politics, in: A. Hurrell and N. Woods (eds.), Inequality, Globalization, and World Politics (1999), 33.

79 David P. Fidler, A Kinder, Gentler System of Capitulations? International Law, Structural Adjustment Policies, and the Standard of Liberal, Globalized Civilization, 35 Texas ILJ (2000), 403. 
any intention of altering the hierarchical basis on which order has traditionally been maintained, even though that hierarchy will not serve to meet the more complex challenges of order in a globalizing world."

In terms of the strategy of substantive pluralization of international law, international lawyers would acknowledge that key traditional principles (e.g., self-determination and non-intervention) and new rules championed and crafted by developing countries (e.g., special and differential treatment in international trade law and the EEZ) form part of contemporary international law. The harder question is to what extent did Third World application of these traditional and new principles during the "revolt against the West" change the substance of international legal dynamics.

In the Cold War period, Third World use of the principle of selfdetermination focused on "external self-determination," or freedom from foreign rule or control.81 As decolonization reached its terminus with the end of the old European empires, the principle of external self-determination lost some of its edge in terms of Third World international legal strategy. The area of the most heated discourse in connection with the principle of selfdetermination in the post-decolonization period has been "[i]nternal selfdetermination, which means the right to authentic self-government, that is, the right for a people really and freely to choose its own political and economic regime". ${ }^{22}$ Debates about whether international law recognizes a right to democracy is one of the best examples of how the international law on selfdetermination has dramatically shifted from the substantive manner in which the Third World used it during the Cold War. ${ }^{83}$

This shift poses problems for the Third World's substantive pluralization strategy because the focus on internal self-determination conflicts with the Third World's strong support for a near absolute principle of nonintervention in the domestic affairs of other states. During decolonization, developing countries argued that international law allowed states to assist peoples struggling for external self-determination; ${ }^{84}$ but, beyond that, the

80 Woods, above n.78, 35 .

81 Cassesse, above n.39, 72 (arguing that the right of self-determination for colonial peoples "only concerns external self-determination, that is, the choice of the international status of the people and the territory where it lives").

82 Cassese, above n.39, 101.

83 See, e.g., Thomas M. Franck, The Emerging Right to Democratic Governance, 86 AJIL (1992), 46; Gregory H. Fox, The Right to Political Participation in International Law, 17 Yale JIL (1992), 539; Brad R. Roth, Governmental Illegitimacy in International Law (1999).

84 Cassesse, above n.39, 199-200 (noting that international law allowed states to "provide economic, political and logistical support to liberation movements, as well as sending arms and ammunitions"). 
principle of self-determination did not allow states to intervene in the domestic affairs of states. Foreign support for the internal self-determination of a people against a non-representative government can only legally occur if the nonintervention principle contains an exception for such action. Third World interpretations and applications of the non-intervention principle during the Cold War recognized no such exception, making this state practice complicated to apply when the self-determination debate now focuses on substantive harmonization through preference for democratic government.

The Third World emphasis on a strong non-intervention principle also ran into trouble in the post-Cold War world. Controversial policies pursued by international financial institutions, such as "structural adjustment," sought to change radically the nature of economic policy in many developing countries to fit a neo-liberal model developed and utilized by the West.85 Western-led "good governance" initiatives also saw the governance practices of developing countries scrutinized by powerful developed states and international organizations. ${ }^{86}$ The "good governance" movement converged with not only the triumph of neo-liberal economic policies but also the growing support for a democratic entitlement in international law. As Roth observed, "[d]emoractic entitlement proponents seek, to one extent or another, to license 'pro-democratic' interferences in the internal processes of sovereign states." ${ }^{77}$ In the face of these efforts by powerful Western countries and the international institutions they controlled, the strong non-intervention principle championed by the Third World during the Cold War was in danger of becoming a distant memory.

In terms of the EEZ principle, it can be described as an international legal success story because it not only appeared in UNCLOS 88 but also rapidly entered into customary international law. ${ }^{89}$ This success story can, however,

85 Bob Deacon, Social Policy in a Global Context, in: Inequality, Globalization, and World Politics, above n.78, 220 ("Requiring governments who need access to loans to open their countries to free trade, to reduce their public expenditures, and to ensure a non-inflationary monetary policy has been argued by many to be the cause of impoverishment, the further indebtedness of many countries, and the political exhaustion of potential opposition forces").

86 See, e.g., World Bank, Governance: The World Bank's Experience (1994); International Monetary Fund, Good Governance: The IMF's Role (1997). For a TWAIL critique of the good governance movement, see James Thuo Gathii, Good Governance as a Counter Insurgency Agenda to Oppositional and Transformation Social Projects in International Law, 5 Buffalo Human Rights LR (1999), 107.

87 Roth, above n.83, 420.

88 UNCLOS, above n.58, arts. 55-75.

89 R. R. Churchill and A. V. Lowe, Law of the Sea (2nd ed. rev., 1988), 134 ("By about 1976 the idea of the EEZ had become so firmly accepted by most 
be pushed critically in order to evaluate its substantive impact on international law. First, Churchill and Lowe argue that the EEZ has not "led to any fundamental redistribution of the ocean's resources - as many developing countries have argued it would and should" because "few developing countries are among the main beneficiaries of EEZs." "90 They further observe that "African, Garibbean and Middle Eastern States, in particular, come off badly" because "[n]ot only do most such States have small EEZs, their EEZs are poor in resources." "91 Of the top fifteen beneficiaries of EEZs, only seven are developing countries, and only one developing country is in the top seven.92 Churchill and Lowe acknowledge that some developing states benefited from establishing EEZs through increasing their fishing catch by reducing foreign fishing or charging licensing fees on foreign fishing fleets. ${ }^{93}$ The EEZ's introduction into international law has not, further, produced any redistribution of non-living resources. ${ }^{94}$

Second, the rapidity with which the EEZ made its way into international law, especially custom, suggests that the EEZ principle, while novel, was sufficiently attractive to developed countries to generate general and consistent state practice (e.g., access to economic resources and a regime respecting freedom of navigation in and through the EEZ). In this respect, the EEZ was classically Westphalian in that the principle applied to all coastal states and represented an extension of coastal state jurisdiction over natural resources, thus conferring on the state more power in the international system. The EEZ's development resonates with Trimble's observation that states embrace international legal rules that are "very congenial to governments" and that "justify or legitimate the practical exercise of state power."95 In short, the EEZ conceptually differs from other Third World proposals exclusively aimed at improving the international legal situation of developing countries.

The Westphalian reciprocity in the EEZ principle may be one reason why this rule of international law is rarely, if ever, raised in contemporary debates about the plight of the Third World in the era of globalization. One

UNCLOS participants that since then a growing number of Statcs-some seventyfour as of 1987 -have unilaterally claimed EEZs without waiting for UNCLOS to end or the Convention to come into force").

90 R. R. Churchill and A. V. Lowe, The Law of the Sea (3rd ed., 1999), 177. Sec also predictions of this outcome in Churchill and Lowe, above n.62, 138-141 and Churchill and Lowe, above n.89, 147-149.

91 Churchill and Lowe, above n.90, 177.

92 Churchill and Lowe, above n.90, 178.

93 Churchill and Lowe, above n.90, 177-178.

94 Churchill and Lowe, above n.90, 179.

95 Phillip R. Trimble, International Law, World Order, and Critical Legal Studies, 42 Stanford LR (1990), 834. 
does not see the EEZ brought forth as a substantive precedent for addressing the problems the Third World currently faces or for creating non-reciprocal rules that advantage developing countries. As with the principle of selfdetermination, international affairs have changed sufficiently to tarnish the EEZ's original luster as a success story of Third World influence in international law.

The "revolt against the West" on foreign direct investment and the CHM have suffered a substantive fate different from special and differential treatment in international trade law and the EEZ in the law of the sea. The thick and still growing forest of bilateral investment treaties (BITs) between capital-exporting and capital-importing states ${ }^{96}$ has obscured the developing world's challenge to customary international legal rules on foreign direct investment. As a general matter, the rules in BITs closely approximate the old customary rules, such as the Hull Doctrine, than the position staked out by developing countries in the Cold War period. ${ }^{97}$ Although arguments can be made that the rules and standards in BITs, such the principles of prompt, adequate, and effective compensation for expropriations ${ }^{98}$ and of fair and equitable treatment of investors, ${ }^{99}$ do not represent customary international law, such claims seem rather academic when capital-exporting countries rely on treaty law rather than custom in protecting foreign direct investments made by their nationals in developing countries.

The CHM remained a subject of intense controversy after adoption of UNCLOS in 1982. Leading developed countries, including the United States, refused to join UNCLOS because of the provisions relating to the CHM concept, namely Part XI. ${ }^{100}$ UNCLOS itself did not enter into force for

96 UNCTAD, Bilateral Investment Treaties Quintupled During the 1990s, Press Release, Dec. 12, 2000, UNCTAD Doc. TAD/INF/PR/077 (reporting on the approximately 2,000 bilateral investment treaties in existence).

97 On the substantive content of BITs, see generally Rudolf Dolzer and Margrete Stevens, Bilateral Investment Treaties (1995).

98 Andrew T. Guzman, Why LDCs Sign Treaties that Hurt Them: Explaining the Popularity of Bilateral Investment Treaties, 38 Virginia JIL (1998), 687 (arguing "that BITs offer no evidence concerning the rules of customary international law that govern compensation for appropriations").

99 See Stephen Vasciannie, The Fair and Equitable Treatment Standard in International Investment Law and Practice, 70 BYIL (1999), 157-158 (arguing that "one would be hard-pressed to identify supportive opinio juris, particularly on the part of developing States" that the "fair and equitable treatment" provision found in BITs represents customary international law).

100 George Galdorisi, The United States and the Law of the Sca: Changing Interests and New Imperatives, 4 Naval War College Review (Autumn 1996), http://www.nwc.mil/press/review/1996/autumn/law-a96.htm (noting that the United States, Great Britain, France, Japan, Canada, and the Sovict Union 
over a decade, partly because of developed-country opposition to Part XI. Eventually, Part XI of the Convention was significantly amended in 1994 through another international agreement to accord with the views of developed countries on how resources in the area should be exploited. ${ }^{101}$ Although the 1994 agreement reaffirmed that the resources of the seabed and ocean floor and subsoil thereof beyond the limits of national jurisdiction were the "common heritage of mankind," 102 its substantive content bears the imprimatur of developed countries not the Third World. ${ }^{103}$ Finally, the failure of deep sea-bed mining to develop as predicted in the late 1960s made the CHM controversy seem like a "tempest in a teapot" with no practical value for developing countries. 104 On both the substantive rules on exploitation of deep sea-bed resources and the economic benefits deep sea-bed mining would generate for developing countries through international wealth redistribution, the Third World lost.

The final aspect of the Third World's substantive pluralization strategy reviewed above was the NIEO, and this article has already mentioned the TWAIL argument that this project failed completely to leave its mark on international law. Other analysts likewise see the NIEO as a failed endeavor. Redclift and Sage argued that "the proposals for the NIEO were given a hostile response by the North, whose strategy of foot-dragging and referral ultimately led to their being overtaken by other developments." 105 As noted above, key elements of the NIEO agenda-external self-determination, nonintervention, transformed rules on foreign direct investment, special and differential treatment in international trade law, and exploitation of resources of the deep sea-bed for the benefit of developing countries-lost relevance, proved less effective than anticipated, or were directly defeated by developed-

refused to sign UNCLOS).

101 See Agreement Relating to the Implementation of Part XI of the United Nations Convention on the Law of the Sea, July 28, 1994 [hereinafter Part XI Convention].

102 Part XI Convention, above n. 101, Preamble.

103 Churchill and Lowe, above n.90, 238 (noting that the modifications to Part XI of UNCLOS achieved through the 1994 agreement were made "to meet the objections to Part XI of the major western States").

104 Galdorisi, above n. 100 (reporting that deep-sea bed mining has not yet occurred and that prospects for deep sea-bed mining are blcak); Churchill and Lowe, above n.90, 253 ("Commercial mining is still some way off; and the discoveries of substantial land-based reserves of nickel, copper and cobalt in Canada and elsewhere and of manganese nodules within the coastal watcrs of Papua New Guinea are likely to postpone even further resort to the complex, expensive technologies for recovering minerals from the abyssal depths").

105 Michael Redclift and Colin Sage, Resources, Environmental Degradation, and Incquality, in: Inequality, Globalization, and World Politics, above n.78, 129. 
country counterattack.

The NIEO effort in the 1970s involves more components than analyzed in this article, and declaring the effort a complete failure without more systematic analysis might be too harsh. At the same time, TWAIL arguments that the NIEO was a failure are powerful given what happened to specific aspects of this radical agenda and the general developments in international relations after the Cold War. More broadly, what the TWAIL position on the NIEO essentially means is that the substantive pluralization strategy undertaken during the "revolt against the West" to push back Western influence and ideas and create space for Third World alternatives did not achieve significant and lasting success. From the TWAIL perspective, picking over the carcass of the NIEO for international legal scraps still remaining from the revolt seems rather unhelpful.

\section{III.B. Homogenization regained}

The flip side of the collapse of the pluralization strategies of the Third World is the attempted harmonization of Westphalian civilization by Western states. Events since the end of the Cold War have seen Western and Westernized states pushing hard to homogenize Westphalian civilization on their political, economic, and cultural terms. Globalization and its many processes are leading Westphalian civilization into a third stage of harmonization. The first stage occurred after the Peace of Westphalia when European states agreed on a framework for inter-state order and stability. The second stage transpired in the "age of Empire" when Westphalian civilization universalized its structure and some of its domestic substance. The third stage is the era of globalization in which the internationalized, pluralistic Westphalian civilization of the Cold War period is transforming into a globalized, liberal civilization.

This on-going transformation of international relations worries scholars concerned about the Third World because this third stage of the harmonization of Westphalian civilization bears disturbing resemblances to the second stage and its standard of civilization, capitulations, and imperialism. Anghie argued, for example, that "the essential structure of the civilizing mission may be reconstructed in the contemporary vocabulary of human rights, governance, and economic liberalization."106 Kingsbury likewise observed:

Emerging liberal thinking about the international legal order argues increasingly that it is possible to divide the world into zones, with a

106 Anghie, above n.14, 80. See also Fidler, above n.20, 146-149 (arguing that the standard of civilization has returned to world politics and international law). 
liberal zone of law, constituted by liberal states practicing a higher degree of legal civilization, to which other states will be admitted only when they meet the requisite standards. This is in some respects a continuation of recurrent patterns in the history of Western legal thought, traceable . . . in James Lorimer's late-nineteenth century division of the world into a hierarchy of civilized nations, barbarous humanity, and savage humanity. 107

Rapporteurs at a February 2000 conference on "International Law and the Developing World: A Millennial Analysis" concluded that panel participants contributed to the emergence of one central theme: "international law is biased against the developing world."108

In short, Western intolerance toward "the other" has returned with a vengeance and animates contemporary international law. Knowledge that the previous pluralization strategies undertaken during decolonization collapsed without many discernables traces in international law deepens the challenge faced by TWAIL scholars. The new quest for a post-hegemonic global order faces the entrenched political structure of Westphalian civilization, the surging global (governmental and non-governmental) dynamics of liberalism, and the disarray (and perhaps demoralization) of developing states.

\section{III.C. Third World opposition and international law in the post-Cold War period}

The failure of the Third World pluralization strategy and the resurgence of Western homogenization reviewed in the previous two sections does not mean that Third World opposition to aspects of international law and international legal developments has been non-existent in the post-Cold War period. Third World countries have unified in the face of certain international legal controversies and have contributed to outcomes more favorable to perceived Third World interests. For purposes of illustration,

107 Benedict Kingsbury, Sovereignty and Inequality, in: Inequality, Globalization, and World Politics, above n.78, 90. Sec also Makau Mutua, Savages, Victims, and Saviors: The Metaphor of Human Rights, 42 Harvard ILJ (2001), 201, 204 (arguing that the human rights movement employs a "damning metaphor" that depicts a contest pitting savages against victims and saviors in which the savior is the West, meaning that the "human rights corpus, though well-meaning, is fundamentally Eurocentric").

108 Poppi Hagan and Zachary Lomo, Symposium Panel Report-International Law and the Developing World: A Millennial Analysis: Pancl I: Post-Colonial Statehood, Legitimacy, and International Governance, 41 Harvard ILJ (2000), 599. 
three examples can be analyzed briefly: Third World opposition to (1) the failed Multilateral Agreement on Investment (MAI); (2) the effort to link trade benefits within the WTO to compliance with international labor standards; and (3) U.S. and European attempts to weaken safeguard provisions, such as the right to engage in compulsory licensing, in the WTO Agreement on Trade-Related Aspects of Intellectual Property Rights (TRIPS).

The MAI represented an attempt, based within the Organization for Economic Cooperation and Development (OECD), to create a multilateral treaty for international legal rules on foreign direct investment. ${ }^{109}$ This effort sought to move international law on foreign direct investment away from the bilateral path blazed by BITs toward a harmonized, global set of rules to facilitate and protect foreign direct investment. Developed countries and corporations based in them pushed for the MAI within the OECD.110 The MAI process collapsed in 1998 because of opposition generated by nongovernmental organizations and developing-country governments."'!

The 1990s also witnessed an effort by developed countries, including the United States and the European Union, to link compliance with international labor standards to the enjoyment of trade benefits under WTO agreements, such as GATT. The idea behind the linkage was to use access to markets as an instrument to force Third World countries to raise their labor laws and practices to internationally recognized levels. At both the Singapore and Seattle WTO ministerial meetings, developing countries presented united opposition to making the trade-labor linkage part of WTO policy and law.112 Such Third World opposition ensured that international trade law under the WTO would not be radically changed to include the linkage.

Another WTO controversy that saw effective Third World opposition to Western-led international legal maneuvers involved the ability of developing countries to use parallel importing and compulsory licensing to increase the availability of and access to essential drugs and medicines in connection with serious public health problems, such as HIV/AIDS. The

109 On the MAI generally, see Steven J. Canner, The Multilateral Agreement on Investment, Cornell ILJ (1998), 657 and David Henderson, The MAI Affair: A Story and Its Lessons (1999).

110 Peter T. Muchlinski, The Rise and Fall of the Multilateral Agreement on Investment: Where Now?, 34 International Lawyer (1999), 1039 (noting that the United States and the European Union pushed the MAI proposal within the OECD).

111 Muchlinski, above n.110, 1048-1049.

112 David P. Fidler, International Law and Global Public Hcalth (2000), 444. 
United States, supported by the European Union and major pharmaceutical companies, took a hard line against developing countries, such as South Africa and Thailand, which sought to use parallel importing and compulsory licensing as part of the policy response to the growing HIV/AIDS epidemic in their respective territories. ${ }^{113}$ Third World governments, supported by nongovernmental organizations, successfully forced the United States and the European Union to retreat and recognize the primacy of public health over patent protection in the WTO Declaration on the TRIPS Agreement and Public Health issued at the Doha Ministerial Meeting in November 2001.114

These examples illustrate that the Third World has forged unified positions vis-à-vis Western-initiated international legal efforts. Such efforts are, however, a far cry from the ambitious pluralization strategy undertaken by Third World countries during the Cold War. First, in each example described above, the Third World was on the defensive in the face of Western-led international legal strategies. Procedurally and substantively, the Third World reacted to the international legal agenda being set by the West in different areas. As noted above, the Third World's earlier pluralization strategy exhibited the opposite dynamic - the West was on the defensive in the face of procedural and substantive reform championed by developing countries.

Second, in the MAI and TRIPS controversies, global nongovernmental activism was as or more prominent than opposition from Third World governments. ${ }^{115}$ During decolonization and the Cold War, the Third World mounted its procedural and substantive challenges to international law

113 See Caroline Thomas, Trade Policy, the Politics of Access to Drugs and Global Governance for Health, in: K. Lee (ed.), Health Impacts of Globalization: Towards Global Governance (2003), 182-185.

114 See Agreement on Trade-Related Aspects of Intellectual Property Rights, Dec. 15, 1993 [hereinafter, TRIPS]; WTO, Declaration on the TRIPS Agreement and Public Health, WT/MIN(01)/DEC/2, Nov. 14, 2001, http://www.wto.org/english/thewto_e/ minist_e/min01_e/mindecl_trips_e.htm. On the background of this Declaration, see Ellen 't Hoen, TRIPS, Pharmaceutical Patents, and Access to Essential Medicines: A Long Way from Seattle to Doha, 3 Chicago JIL (2002), 27.

115 See Muchlinski, above n.110, 1049 ("The political opposition to the Agreement generated by the NGO community undoubtedly made a significant contribution by raising awareness of its one-sided nature, and by offering an organized critiquc based on the unaccountability of MNEs and of the multilateral economic organizations that were trying to introduce the MAI."); 't Hoen, above n.114, 3334 (discussing important role non-governmental organizations played "in drawing attention to the provisions of TRIPS that can be used to incrcase access to medicines"). 
through state action that did not rely on the participation and support of nonstate actors. Although the influence of non-governmental organizations in the MAI and TRIPS controversies reflects a shift from international toward global governance, the shift may signal the further deterioration of the Third World's quantitative advantage it marshaled effectively during decolonization.

Third, in each of these contemporary cases, the Third World was defending the status quo rather than promoting an alternative international legal vision. As mentioned above, most Third World countries have entered into BITs, meaning that they have accepted, through a network of bilateral agreements, the substantive protections for foreign investors and investments the MAI would have included. ${ }^{116}$ In other words, the worldwide web of investor-friendly BITs represents an effective substitute for the MAI in terms of substantive legal protections for foreign direct investment. Third World concern for the MAI did not resemble the substantive challenge mounted during the period of decolonization to the traditional rules of customary international law on foreign direct investment. From the point of view of capital-exporting states, the MAI was ultimately expendable and not worth the fight because, substantively, these states have achieved the international legal protections they want through BITs. 117

In connection with the controversial linkage of trade and labor standards, the Third World was defending the status quo under international trade law-trade liberalization is not directly conditioned on the achievement of other social objectives, such as higher labor standards. ${ }^{18}$ The Third World's efforts on international trade law in the 1960s and 1970s rejected the status quo and sought to create new substantive law through special and preferential treatment in GATT for developing countries.

With regards to access to drugs and medicines, again the Third World found itself defending principles contained in existing international law. Before the creation of the WTO, many developing countries refused to recognize patents on pharmaceutical products in an effort to ensure accessibility and

116 Muchlinski, above n.110, 1038 (noting that "the draft MAI was based on earlier models of binding investor protection standards, leading it to be crafted as an investor and investment protection and promotion agreement").

117 Muchlinski, above n.110, 1053 (noting British doubts "whether there is a high priority for action on investor protection rules . . given the existing network of bilateral investment agrecments.").

118 The only trade-labor link in GATT appears in Article $\mathrm{XX}(\mathrm{e})$, which allows contracting parties to restrict trade in products made by prison labor. 
affordability to essential drugs and medicines. ${ }^{119}$ For developing countries joining the WTO, TRIPS required that pharmaceutical patents be recognized.120 TRIPS effectively harmonized global treatment of pharmaceuticals under patent law on terms favored and promoted by the West, squeezing out the pluralism that previously existed on granting patents on pharmaceutical products.

The TRIPS controversy did not involve the Third World rejecting TRIPS and its Westernized harmonization of patent law but focused on whether TRIPS allowed WTO member states to engage in parallel importing and compulsory licensing, which TRIPS clearly does. ${ }^{121}$ Part of the reason the United States and European countries backed down was because their legal position was weak given that TRIPS does not regulate parallel importing and recognizes the right to engage in compulsory licensing. Further, the catastrophic scale of the HIV/AIDS debacle in the developing world, especially sub-Saharan Africa, ${ }^{22}$ supported Third World opposition to the hard line taken by the United States and Europe. Having to rely for support on a disaster of historic proportions provides telling evidence of how radically transformed the context of Third World opposition in international law has become from the days of the "revolt against the West."

Fourth, these three examples of post-Cold War opposition in international law do not connect strategically the way in which Third World governments crafted their earlier pluralization movement. As the NIEO demonstrated, the Third World linked its international legal reform efforts into a comprehensive procedural and substantive vision. Discerning a comprehensive strategic vision from the Third World in the MAI, trade-labor linkage, and TRIPS controversies is difficult, if not impossible. The disintegration of the comprehensive NIEO vision was, of course, underway over the course of the 1980s and 1990s as the debt crisis, collapse of Soviet communism, and the acceleration of globalization transformed the political landscape of world affairs. The three examples reviewed above suggest that this transformation of world politics has also transformed Third World opposition from an offensive, strategic campaign to defensive, ad hoc

119 Bernard Pecoul et al, Access to Essential Drugs in Poor Countrics: A Lost Battle?, $281 \mathrm{~J}$ American Medical Association (1999), 361; Fidler, above n.112, 259.

120 TRIPS, above n.114, art. 27.

121 TRIPS, above n.114, arts. 6 (providing that TRIPS does not apply to parallel importing) and 31 (setting out conditions for using compulsory licenses).

122 See UNAIDS, AIDS Epidemic Update: December 2002 (2002) on the scale of the HIV/AIDS pandemic. 
reactions.

\section{The quest for a post-hegemonic global order: The tolerance/intolerance paradox}

\section{IV.A. Pluralism and solidarism in international relations theory}

The challenge facing the new quest for a post-hegemonic global order connects to a long-running discourse in international relations and international legal theory about pluralism and solidarism. This discourse, generally speaking, assumes the continuation of the system of sovereign states interacting in a condition of anarchy (i.e., the structure of Westphalian civilization). Crudely stated, pluralism is associated with the acceptance of political, economic, and cultural diversity at the domestic level, while solidarism posits the need for similitude at the domestic level among states.

Under pluralism, the scope of international society among states is limited because the common interests and values of diverse states do not penetrate deeply into domestic affairs. The pluralist conception of international society "highlights the procedural and institutional features of the international system . . . , such as the exchange and treatment of diplomats, treaty law, the requirement of reciprocity, and the principle of nonintervention." 123 For pluralists, "international society functions as a pragmatic dynamic that accommodates cultural difference." 24 As a reflection of international society, international law in pluralistic thought is limited and mechanical-it deals primarily with the formal interaction of states across borders because the internal aspects of sovereignty are off limits. Linklater's observation that "[p]luralism has been accepted and solidarism resisted"125 could characterize the Cold War period.

In solidaristic thought, international law's scope is both expanded and reduced. The scope expands because the body of shared values and common interests among solidaristic states incorporates aspects of domestic politics, economics, and culture, providing a stronger platform for using international law to shore up such values and interests (e.g., the use of international trade law to pursue free trade). The scope decreases because the likemindedness of solidaristic states means that international law is often not needed to regulate certain inter-state interactions (e.g., the paucity of treaties between developed, capitalist economies on the treatment of foreign direct investment). ${ }^{126}$

123 David P. Fidler and Jennifer M. Welsh, Introduction, in: Empire and Community, above n.16, 52 .

124 Fidler and Welsh, above n. 123, 52.

125 Linklater, above n.36, 106.

126 Guzman, above n.98, 680 (indicating that "no two developed countrics have 
The typical conclusion from comparing pluralism and solidarism is that solidarism supports a more robust system of international law. In other words, to produce an effective and efficient system of international law requires a certain level of solidarism in the international system at the level of domestic politics, economics, law, and culture. Bull noted that most historical international societies "were all founded upon a common culture or civilisation, or at least on some of the elements of such a civilisation: a common language, a common epistemology and understanding of the universe, a common religion, a common ethical code, a common aesthetic or artistic tradition."127 By contrast, pluralism seeks to cordon off domestic affairs from the realm of international law, thus directing international law into a mechanical, limited set of functions that do not (and perhaps cannot) connect in any deep way with cultural affinities.

\section{IV.B. The tolerance/intolerance paradox}

From this overview, solidarism can be linked to intolerance and pluralism with tolerance in connection with international law. To seek similitude among states domestically is to be intolerant of difference. To advance pluralism among states is to be tolerant of difference. Intolerance and tolerance can exist simultaneously in international relations-intolerance within a solidaristic set of states and tolerance between the solidaristic states and other states that do not share the same domestic political, economic, legal, or cultural preferences. Under this scenario, clear boundaries would exist between the solidaristic and the pluralistic systems. One could think of the Cold War system as reflecting this dynamic: solidarism existed among a group of liberal states and among a group of socialist states, and these two groups had pluralistic relations with the developing world.

This characterization of the Cold War system does not accurately capture what happened in those difficult decades. The picture painted is too simplistic. Part of the simplicity reflects a failure to focus on the tolerance/intolerance paradox. For tolerance (and thus pluralism) to be sustained in international relations, states must reach solidarity on the importance of the value of pluralism. Solidarity is, however, a function of intolerance-the unwillingness to accept behavior different from prescribed norms. Tolerance requires, thus, solidarism among states that pluralism should be an important principle of inter-state relations and international law. Tolerance, in other words, emerges out of intolerance.

Some historical examples of this tolerance/intolerance paradox

entered into a BIT with one another").

127 Hedley Bull, The Anarchical Society: A Study of Order in World Politics (1977), 16. 
illustrate the point. Solidarism on pluralism as an organizing principle occurred in Europe in the aftermath of both the Thirty Years' War and the French Revolution/Napoleonic wars. Out of the Peace of Westphalia came the basic organizing principle of non-intervention in the domestic affairs of states. The wars triggered by the French Revolution threatened this commitment to non-intervention as the revolutionary transformation of internal France shook the stability and order of the international system in Europe. Tension between the powers of the Holy Alliance and Great Britain after the Napoleonic wars concerned whether pro-monarchical intervention should replace the principle of non-intervention as the operative norm. British adhesion to the traditional, pluralistic balance-of-power framework eventually prevailed over the solidaristic vision of the pro-monarchist powers.

The quest for a post-hegemonic global order cannot, therefore, be a first-order quest for pluralism. The quest has to be for solidarism among states that pluralism needs to be the operative principle among states having different domestic forms of government, economic practices, and cultural and civilizational heritages. The quest needs to be an intolerant pursuit of tolerance in order for pluralism to become an effective principle in international law.

The historical examples of the aftermath of the Thirty Years' War and the French Revolution/Napoleonic wars provide insight into another aspect of the tolerance/intolerance paradox: to achieve solidarism on pluralism as an operative principle in international law and relations, some level of solidarism must already exist among states. The European states had already developed a common history, common forms of political and economic organization, common religious traditions, and a sense (even if only among aristocrats and merchants) of a shared heritage and destiny. This preexisting similitude must, logically, also be the product of intolerance (i.e., other forms of political, economic, and cultural organization have been rejected). Pluralism as an operative international legal principle must, therefore, have solidarism (intolerance) not only as a foundation but also as the objective of political action.

The tolerance/intolerance paradox poses serious problems for TWAIL appeals for a more tolerant post-hegemonic global order. TWAIL scholarship challenges the legitimacy of the global structure provided by Westphalian civilization for many developing nations because the structure is biased in favor of the West. The "revolt against the West" turned out to be a "revolt from within the West" as developing states largely accepted their incorporation into Westphalian civilization ${ }^{128}$ and attempted to use the

128 Hedley Bull and Adam Watson, Conclusion, in: The Expansion of International Society, above n.32, 433 ("Indeed, the most striking feature of the global international society of today is the extent to which the states of Asia and Africa 
mechanisms of this civilization, including international law, to render it more tolerant of political, economic, and cultural differences. Anghie noted that " $[t]$ he optimistic international lawyers of the 1960s, even those notable scholars from developing nations, who were the most trenchant critics of the Eurocentric character of international law, were hopeful that the acquisition of sovereignty by developing nations and participation in international legal forums would result in the creation of a truly universal, just, and equal international system." 129

Success in this endeavor proved either dependent on balance of power politics (e.g., developing countries playing the superpowers off against each other to create structural space to maneuver) or substantively ephemeral (e.g., the "victory" achieved in the area of customary international law on foreign investment). But, is today's quest for a post-hegemonic global order really a quest for a radically different structure for human interaction that extracts the Third World from the structure of Westphalian civilization? Or is it a project designed to re-direct Westphalian solidarism toward its older substantive commitment to pluralism? Is it a plea for a more humane form of intolerance?

\section{The role of intolerance in international law}

\section{V.A. International law and intolerance}

The ferment in international relations in the post-Cold War era encouraged international legal theorists to explore basic questions about international law anew. Franck characterized the new environment of inquiry in this way:

The questions to which the international lawyer must now be prepared to respond, in this post-ontological era, are different from the traditional

have embraced such basic elements of European international society as the sovereign state, the rules of international law, the procedures and conventions of diplomacy and international organization").

129 Anghie, above n.14, 75. See also Antony Anghie, Civilization and Commerce: The Concept of Governance in Historical Perspective, 45 Villanova LR (2000), 888-889 (pointing out that "developing states that protested against certain rules, which, they claimed, furthered colonialism, have accepted in large part the basic principles of international law"); and James Thuo Gathii, International Law and Eurocentricity, 9 EJIL (1998), 189 (characterizing scholarship of developing-world international legal scholars in two different catergories: the integrationists who saw potential in developing-country participation in international law through legal reform, and the nationalists who saw no hope for developing countries within the 
inquiry: whether international law is law? Instead, we are now asked: is international law effective? Is it enforceable? Is it understood? And, the most important question: Is it fair? 130

Looking at the TWAIL quest for a post-hegemonic global order in light of the tolerance/intolerance paradox raises another important theoretical question: Is international law intolerant?

TWAIL analysis of how the encounter between the West and the nonWestern world through nineteenth century imperialism and colonialism shaped international law is, in essence, a study of how Eurocentric intolerance drove international law in this period. Contemporary worries about liberalism's hegemony in international relations also reflect concerns about intolerance shaping international legal doctrines and discourse. The solidaristic and pluralistic perspectives on international law and relations turn out to be perspectives on different kinds of solidarism, or different forms of intolerance.

Whether intolerance has some deeper theoretical importance in international law is not, in fact, a novel question. Kingsbury observed that "a persistent feature of international law, [is] the problem of reaching normative judgments in a heterogenous world while simultaneously accommodating deep cultural, social and religious differences." 131 Phrased differently, Kingsbury noted that international law constantly struggles to balance intolerance (i.e., normative judgments in a heterogenous world) with tolerance (i.e., accommodating deep cultural, social and religious differences). But note that Kingsbury's observation suggests that intolerance plays an important function in international law.

Gong's study of the standard of civilization in international society led him to similar conclusions about the role of intolerance in international law. Gong argued that "[s]ome standard of civilization will remain a feature of any international society wherein cultural diversity and pluralism exists coetaneously with hierarchy and anarchy, regardless of how strong the ties of society are."132 Important to Gong's conclusion is the structural context of sovereign states interacting in a condition of anarchy, meaning that the political structure of international relations plays a critical function in how intolerance affects international law. Anghie also questioned whether intolerance remains integral to the substantive concepts alive in contemporary

existing structure of international law and advocated radical restructuring).

130 Thomas M. Franck, Fairness in International Law and Institutions (1995), 6.

131 Benedict Kingsbury, Confronting Difference: The Puzzling Durability of Gentili's Combination of Pragmatic Pluralism and Normative Judgment, 92 AJIL (1998), 713.

132 Gong, above n.34, 248. 
world politics: "The more alarming and likely possibility is that the civilizing mission is inherent in one form or another in the principal concepts and categories that govern our existence: ideas of modernity, progress, development, emancipation, and rights."133

\section{V.B. Structural and substantive tolerance/intolerance}

How, then, in the anarchical structure of international relations dominated substantively by liberal political and economic thinking do states and peoples calibrate intolerance in international law to improve the lot of the Third World? Conceptually, the relationship between intolerance and international law is a function of the amount of structural and substantive tolerance in the international system.

Structural tolerance concerns the amount of flexibility in the international system regarding the hierarchy and distribution of power. A structurally intolerant system is one in which small changes in the hierarchy and distribution of power threaten order and stability. A structurally tolerant system is one in which changes in the hierarchy and distribution of power do not undermine systemic stability. Substantive tolerance involves respect in the international system for different political, economic, and social practices and beliefs within and among states. A substantively intolerant system is hostile to differences in political, economic, legal, and cultural beliefs and practices within and among states. A substantively tolerant system accepts and protects such differences in state interaction.

From historical experience, we can postulate that international law changes rapidly in international systems characterized by structural tolerance and substantive intolerance. The nineteenth century "age of Empire" and the contemporary era of globalization fit this description. Structurally, the scramble for imperial possessions in non-European regions did not destabilize the European balance of power during the nineteenth century. Resistance from non-Western countries to the expansion of European influence did not threaten the hierarchy or distribution of power in the international system significantly, as illustrated by the relative ease with which European states imposed their will on China in the nineteenth century. When imperialism complicated relations among European states seriously, traditional greatpower management of the expanding system kept matters more or less orderly (e.g., the partition of Africa at the Conference of Berlin in 1884-1885). While the growth of European influence in non-Western regions affected balance of power politics among Europe states, ${ }^{134}$ the eventual explosion came from

133 Anghie, above n.14, 80. See also Mutua, above n.2, 37 (arguing that "a certain level of universality is inevitable, and cven desirable" in international law).

134 Hinsley, above n.30, 264-266 (discussing impact of imperialism on the 
within Europe in the form of the World War I. 135

Substantively, the nineteenth century expansion of European power into the non-European world was intolerant, as evidenced by the racism, discrimination, and exploitation meted out to non-Western nations and peoples by the European powers and the United States in their imperial realms and activities. This intolerance fueled the dramatic geographical expansion of the system of international law and substantive changes in international law, such as the standard of civilization, which occurred.

In the era of globalization, the international system is again structurally tolerant. The post-Cold War system accommodated revolutionary changes in the hierarchy and distribution of power without global, systemic instability. The bipolar balance of power seen in the Cold War peacefully gave way to an international system dominated by a single military and economic superpower and its likeminded liberal allies. The system's current hegemons are not interested in territorial acquisition, which also fosters systemic stability. Further, the emergence of new powers, such as China, is partly being channeled through existing international mechanisms (e.g., Chinese membership in the WTO) rather than posing a destabilizing factor in international politics.

As TWAIL scholarship argues, substantive intolerance characterizes international relations in the global era, as liberal concepts of government, governance, law, economics, and human rights dominate international political and legal agendas. Part of this substantive intolerance reflects the growth of Western power in the post-Cold War period, ${ }^{136}$ while part of the intolerance represents the lack of any substantive challenger to liberalism as a normative philosophy. ${ }^{137}$ Hardt and Negri provocatively labeled the political and philosophical power of the liberal West in the era of globalization as "Empire"-a regime "that rules over the entire 'civilized' world." 138 Today's substantive intolerance in the international system reflects, then, a new "age of Empire."

management of great power politics in Europc).

Structural tolerance was also present within Europe during the nineteenth century. German power grew, for example, through unification and war (1866-1868; 18701871) without sparking a crisis in the balance of power. This structural tolerance deteriorated into intolerance in the first decade of the twentieth century, leading to World War I.

136 Samuel P. Huntington, The Clash of Civilizations?, 72 Forcign Affairs (Summer 1993), 39 ("The West is now at an extraordinary peak of power in relation to other civilizations").

137 See, most famously, Francis Fukuyama, The End of History?, The National Interest (Summer 1989), 3.

Michael Hardt and Antonio Negri, Empire (2000), xiv. 
The period of decolonization - arguably the zenith of pluralism in international relations after the global expansion of Westphalian civilizationoccurred in an international system characterized by structural intolerance. The tense, global contest between U.S. and Soviet power made the system hyper-sensitive to actual and perceived power shifts (e.g., the "domino theory"), and the developing world became a key structural component of the balance-of-power calculus for both superpowers.

During the same period, substantive tolerance was present as the system exhibited not only capitalist and socialist governments and economies but also developing-country efforts at non-alignment and domestic political and economic experimentation designed to liberate developing countries from their former subjection to Western power. The competing blocs of states contested at every step many existing rules of international law (e.g., customary international law on the treatment of foreign direct investment) and changes in international law in this period (e.g., human rights), producing difficult times for international law.

From these observations, we can posit that the ideal international system for the quest for a post-hegemonic global order is one characterized by structural and substantive tolerance-in other words, systemic stability and substantive political, economic, and cultural pluralism. International systems exhibiting structural tolerance have been or are characterized, however, by substantive uniformity or hegemony-the nineteenth century imperial system and the post-Cold War system. The international systems that exhibited substantive tolerance-the post-Peace of Westphalia and the Cold War systems - suffered from structural intolerance and a great deal of warfare and violence. The structural intolerance of the Cold War system also produced superpower exploitation of, and abuses in, the Third World.

The quest for a post-hegemonic global order perhaps faces, therefore, a choice between (1) fomenting structural instability in international politics through challenges to the current hierarchy of power (i.e., moving from structural tolerance to intolerance by destabilizing the existing configurations of power in order to create space for Third World pluralism); or (2) fostering pluralism as a common interest and value of the global hegemonic system (i.e., global solidarism on the importance of pluralism). The choice is, then, a choice between a revolt against the West-a challenge to the West's structural hegemony in military, political, and economic power-and a revolt from within the West-an attempt to make the hegemony's substantive agenda more tolerant of the interests and needs of the Third World. 


\section{TWAIL and the quest for a post-hegemonic global order}

TWAIL scholarship provides a powerful critique of how the West has used international law as an instrument of intolerance in its dealings with the Third World. TWAIL analysis of international law contains a desire for international law to promote "unity in diversity" in order to allow the Third World to escape from perceived structural and substantive marginalization in international law and relations. Gathii characterized this effort as a process of "decentering" international legal discourse from its continuing Eurocentricity and denigration of non-Western sources of ideas and practices. ${ }^{139}$ Mutua argued that the TWAIL task involves "reconceptualizing and restructuring international law."140 In addition, like the majority of developing-world international lawyers during the decolonization quest for a post-hegemonic order, TWAIL analysis accepts the basic structure of Westphalian civilization (i.e., sovereign states interacting in a condition of anarchy) but hopes to promote a different substantive ethos for this civilization.141 In short, the TWAIL project appears to be a revolt from within Westphalian framework, not a revolt against it.

Beyond these observations, it is hard to discern common threads in TWAIL scholarship about (1) what kind of tolerance/pluralism to advance (substance); and (2) how to advance tolerance/pluralism in the face of intolerant hegemony (procedure). ${ }^{142}$ Pluralism based on insights from historical

139 James Thuo Gathii, Neoliberalism, Colonialism, and International Governance: Decentering the International Law of Governmental Legitimacy, 98 Michigan LR (2000), 2054.

140 Makau Mutua, Critical Race Theory and International Law: The View of an Insider-Outsider, 45 Villanova LR (2000), 851-852.

141 This dynamic can be seen in Mutua's arguments that "TWAIL believes international law is necessary and important" but that "TWAIL is fundamentally a reconstructive movement that seeks a new compact of international law"). Mutua, above n.2, 36, 38. See also Gathii, above n.3, 2067 (arguing that Third World positions on international challenge prevailing perspectives "and suggest ... that a re-imagining or, indeed, revision of international cconomic and legal relations would not unduly destabilize international society"); Mickelson, above n.5, 413-414 ("These [Third World] authors appear to operate on the basis of the possibility of transforming international society, and indeed might otherwise have found their work difficult to justify. In the end, however, they reject the idea of an alternative model that will simply be set up in place of the existing system. Their focus is on process, on creating structures and a normative foundation for bringing about a just international order").

142 This observation connects with more general concerns that Third World writers on international law "have failed to propose and articulate an alternative approach [to international law] which is inclusive and internally consistent." B. S. 
materialism might be different from pluralism grounded in respect for indigenous, non-Western cultures, to which historical materialism may be just as alien as liberalism. If "unity in diversity" is the rallying cry, then the substantive nature of the diversity needs to be clarified both in terms of the underlying analytical approach and the specific political features of the diversity in question. It is not clear how far TWAIL scholarship has provided ways, to paraphrase Kingsbury, of reaching normative judgments in a heterogeneous world while accommodating deep political, economic, and cultural differences.

Some confusion about the TWAIL quest for a post-hegemonic global order comes from the tension created by the plea for pluralism and the demand for assistance from the West. The call for pluralism often reflects Third World distaste for what Friedman called the "golden straitjacket"143 of liberal economic theory and practice in the era of globalization. Policies of international financial institutions have come under TWAIL attack for their insensitivity to the peculiarities of Third World politics, economics, and culture. 144 The demand for pluralism in economic development policy often comes hand-in-hand with an equally vocal call for the West to transfer wealth and resources and to forgive debt in order to help Third World nations develop on their own terms. This theory of obligation does not resonate with the hegemons; nor does it answer hard questions about how transferred wealth or forgiven debt should be consumed in Third World nations and who should structure such consumption.

Mutua claims that TWAIL "has a basic interest in the internal reconstruction and genuine democratization of Third World states."145 This interest leads to questions about the substantive nature of, and procedural route to, this internal reconstruction and democratization. Does decentering Eurocentric discourse and contextualizing the resulting analysis in order to give more respect to Third World societies produce concrete and realistic blueprints for economic development and poverty alleviation in Third World countries? 146

Chimni, International Law and World Order: A Critique of Contemporary Approaches (1993), 19.

143 Thomas L. Friedman, The Lexus and the Olive Trec: Understanding Globalization (2000), 101-111 (discussing his concept of the "Golden Straitjacket" of the rules of the free market in today's global economy).

144 See, e.g., Antony Anghie, Time Present and Time Past: Globalization, International Financial Institutions, and the Third World, 32 N.Y.U. JILP (2000), 243.

145 Mutua, above n.2, 37.

146 Some commentators are skeptical about this kind of project. Sce Friedman, above n.143, 103 (arguing that "[p]eople can talk about alternatives to the free market 
TWAIL scholarship finds itself somewhere between two extremes on this issue: (1) the extreme represented by the imposition of the "Washington consensus" 147 on economic development (i.e., substantive intolerance); and (2) the extreme represented by a strong rule of non-intervention into the political and economic affairs of sovereign developing states (i.e., substantive tolerance). Developing-country international lawyers during decolonization leaned heavily on the concept of sovereignty and the principle of non-intervention as a strategy to create pluralism in international relations. TWAIL scholarship does not seem drawn to this approach, suggesting that TWAIL positions itself closer to substantive intolerance than the sovereignists of decolonization.

Mutua claimed, for example, that part of the core of TWAIL thinking is not only a rejection of Western hegemony but also a drive "to transformfrom within-Third World cultures, philosophies, and practices that are inimical to human development."148 Mutua's observation contains elements of solidarism-the idea that a universal concept of human development existsand elements of pluralism - the emphasis that transformation is to take place from within rather than being imposed from without. While TWAIL scholarship frowns on the substantive intolerance reflected in such things as the Washington consensus on economic development, it is not clear what kind of intolerance TWAIL scholars prefer and how such intolerance can be created and maintained in international relations.

There seems to be some TWAIL consensus that the statist approach that characterized the decolonization quest for a post-hegemonic order is unlikely to produce results because many Third World states are as much a part of the problem as part of the solution. Some TWAIL scholars place emphasis on local and transnational social movements as engines of reform for the Third World and international law.149 The mass protests against globalization seen from Seattle to Genoa are sometimes invoked as indicia of the potential transformatory power of transnational social movements and non-governmental organizations (NGOs). .150

and global integration, they can demand alternatives, they can insist on a 'Third Way,' but for now none is apparent. This is very different from the first era of globalization").

147 For an analysis of the "Washington consensus," see Moisés Naim, Washington Consensus or Washington Confusion?, Foreign Policy (Spring 2000), 87.

148 Mutua, above n.140, 852.

149 See, e.g., Balakrishnan Rajagopal, From Resistance to Renewal: The Third World, Social Movements, and the Expansion of Intcrnational Institutions, 41 Harvard ILJ (2000), 529.

150 On the importance of non-governmental organizations in contemporary world politics, see Peter Willetts, Transnational Actors and International Organizations in Global Politics, in: The Globalization of World Politics, above n.23, 356. 
Disentangling what these anti-globalization protests represent for the Third World generally and TWAIL specifically is, however, difficult. The views of the groups participating in these protests range from violent destruction of international economic and financial institutions to the peaceful interpretation of international agreements in order to give Third World countries more flexibility in meeting national problems (e.g., interpreting TRIPS to ensure access to essential medicines in developing countries). The TWAIL quest for a post-hegemonic order needs to be more coherent than the unwieldy, opaque conglomeration of global civil society groups protesting globalization at high-profile diplomatic events. TWAIL can be neither a dogma nor a cacophony of contradictory claims.

In addition, global activism by civil society groups at local and global levels (even those hostile toward intolerant Western hegemony) fits easily within liberal conceptions of international relations. ${ }^{151}$ Domestically, liberalism encourages citizen participation in politics through principles such as free speech and the right to vote. Internationally, liberalism focuses on transnational connections between individuals and non-state actors (e.g., NGOs and companies) as part of creating interdependence between societies. ${ }^{152}$ One can analogize between liberalism's tolerance for global civil society activism and the role of free speech in democratic societies. ${ }^{153}$ The right to free speech provides a procedural foundation for political protest, but substantive decisions about policies and laws are made through electoral and legislative processes. Every citizen is free to speak; but this right does not ensure anyone is going to pay attention. Liberal politics in the era of globalization likewise encourages "global free speech," but this space for global discourse does not mean that the discourse generated will affect political and economic decisions made by states and international organizations.

Transnational social movements and NGOs have space today to speak and protest; but states and the international institutions make the substantive

151 Anne-Marie Slaughter, International Law and International Relations, 285 Recueil des Cours (2000), 109 ("The adversarial activist model of NGOs is remarkably consistent with Liberal international relations theory").

152 On liberalism as a theory of international relations, see Timothy Dunne, Liberalism, in: The Globalization of World Politics, above n.23, 162; Scott Burchill, Liberal Internationalism, in: Theories of International Relations, above n.36, 28; Andrew Moravcsik, Taking Preferences Seriously: A Liberal Theory of International Politics, 51 International Organization (1997), 513.

153 See Benedict Kingsbury, First Amendment Liberalism as Global Legal Architecture: Ascriptive Groups and the Problems of the Liberal NGO Model of International Civil Society, 3 Chicago JIL (2002), 183 (arguing that "an operational code resembling First Amendment liberalism has been the de facto guide in the construction of international civil society"). 
decisions. Procedural pluralism in international relations - the involvement of states and non-state actors in international politics and economics-is a core substantive value of the globalized, liberal civilization under construction that TWAIL scholarship opposes. TWAIL reliance on local and transnational social movements and NGOs might, therefore, represent acceptance of a key substantive aspect of the globalized, liberal civilization in the same way that the decolonization period's statist approach represented acceptance of the structural dictates of Westphalian civilization. ${ }^{154}$

\section{Conclusion}

Additional observations about the difficulties faced by the TWAIL quest for a post-hegemonic global order could be made, but TWAIL scholars and symphathizers do not need more reminders of the obstacles their quest confronts. The essential dilemma of the TWAIL quest has been identified many times in international relations theory-finding ground for reform between the extremes of utopianism and realpolitik. ${ }^{155}$ Structurally, the TWAIL quest would be ill-advised to attempt to destabilize the international system by challenging the military, political, and economic hegemony of the West. The current "war on terrorism" has been sparked by a desire by radical Islamic groups to revolt against the West through violence and terror. I cannot see anything but suffering for the Third World in that strategy. The events of September 11, 2001 have already re-shaped global politics in ways that make the United States and its anti-terrorism allies less tolerant of views that challenge Western political and philosophical hegemony.

This leaves the strategy of attacking the substantive intolerance of Western hegemony and working to create a new solidarism of "unity in diversity" and a new pluralism that defines that diversity in a substantively credible manner. This conclusion echoes Falk's argument that "international law and lawyers can best contribute to the prospects of fashioning a more humane type of global civilization by self-confidently entering the dialogic

154 These observations echo those of Chimni, who argued that "[i]t is . . not unusual to see a Third World scholar speaking of rejecting rules which are prejudicial to the interests of developing countries [yet] embracing a theory of international law and world order which seeks to justify and protect the status quo and has little to say on the situation of the developing world. This eventually leads him to assume positions which strengthen that which he had sct out to fight." Chimni, above n. 142, 19.

155 See, e.g., Ian Clark, The Hierarchy of States: Reform and Resistance in International Order (1989), 49-89 (analyzing the traditions of optimism and despair in international relations theory); Jan Aart Scholte, Globalization: A Critical Introduction (2000), 283-314 (analyzing reforms designed to produce a humane global future). 
space between entrenched political power and transnational social forces, acknowledging the relevance of both, but subordinating their autonomy to neither." 156

Key to this strategy are the assumptions that the substantive intolerance witnessed today is (1) more amenable to change than the substantive intolerance that animated international law in the "age of Empire"; 157 and (2) amenable to adjustment through the craft of international law rather than just through power politics. 158 The construction of a globalized civilization "based on genuine universalization" 159 may only be viable in the long run if a new solidarism and pluralism that take into account the interests and needs of the Third World is created intellectually and implemented practically.

TWAIL confronts, however, the sobering fact that this description of the challenge is neither novel nor perhaps persuasive. Bull argued well over twenty years ago that the prospects for international society depended on the development of a consensus among the great powers and other states that took in account the demands of weak and poor countries in Asia, Africa, and Latin America.160 TWAIL scholarship highlights the extent to which (1) those demands are still not heeded; and (2) solidarism has powerfully coalesced around liberal political and economic thinking rather than broadening into a more pluralistic project. Since 1648, the scope of pluralism in international society has been primarily a function of structural tolerance/intolerance in the international system not intellectual discontent with Western arrogance and discourse on the need for more respect for non-Western societies. Pluralism has been pursued in the past when this pursuit served the structural interests of the international system in order and stability not because pluralism would produce a more just and humane world.

In its formative stages, TWAIL seeks to create its own version of what Falk called "dialogic space" in order to chart a new direction for international law's future. In this quest, TWAIL confronts an international system

156 Richard Falk, The Coming Global Civilization: Neo-Liberal or Humanist?, in: A. Anghie and G. Sturgess (eds.), Legal Visions of the 21 st Century: Essays in Honour of Judge Christopher Wecramantry (1998), 32.

See Hardt and Negri, above n.138, 353 (judging "Empire as less bad or better than the previous paradigm of power from the standpoint of the multitude").

Mutua, above n.140, 847 ("Exploitation and repression, for the past five centuries, have been a global phenomenon. The response to them must also be coordinated on a global basis. In a strange twist, international law may facilitate this process by default. The norms, processes, structures and institutions that opcrate under this broad rubric of international law are porous enough to allow a ccrtain degree of mobilization").

Mutua, above n.140, 852.

Bull, above n. 127, 315 . 
structurally and substantively more inhospitable to its message than the system faced by developing-country international lawyers in the period of decolonization. TWAIL conclusions that the decolonization effort to de-center and re-conceptualize international law failed to leave lasting marks on international law's development haunt TWAIL's much more difficult quest today for a post-hegemonic global order. 